\title{
De zwoegers uit het vooronder (2001)
}

\author{
Citation for published version (APA):
}

Verhey, L. F. M. (2001). De zwoegers uit het vooronder (2001). Kluwer. https://doi.org/10.26481/spe.20010101lv

Document status and date:

Published: 01/01/2001

DOI:

10.26481/spe.20010101/v

Document Version:

Publisher's PDF, also known as Version of record

\section{Please check the document version of this publication:}

- A submitted manuscript is the version of the article upon submission and before peer-review. There can be important differences between the submitted version and the official published version of record.

People interested in the research are advised to contact the author for the final version of the publication, or visit the DOI to the publisher's website.

- The final author version and the galley proof are versions of the publication after peer review.

- The final published version features the final layout of the paper including the volume, issue and page numbers.

Link to publication

\footnotetext{
General rights rights.

- You may freely distribute the URL identifying the publication in the public portal. please follow below link for the End User Agreement:

www.umlib.nl/taverne-license

Take down policy

If you believe that this document breaches copyright please contact us at:

repository@maastrichtuniversity.nl

providing details and we will investigate your claim.
}

Copyright and moral rights for the publications made accessible in the public portal are retained by the authors and/or other copyright owners and it is a condition of accessing publications that users recognise and abide by the legal requirements associated with these

- Users may download and print one copy of any publication from the public portal for the purpose of private study or research.

- You may not further distribute the material or use it for any profit-making activity or commercial gain

If the publication is distributed under the terms of Article $25 \mathrm{fa}$ of the Dutch Copyright Act, indicated by the "Taverne" license above, 
De zwoegers uit het vooronder 
Deze uttgave is gedrukt op chloorvij papier

(C) 2001 L.F.M. Verhey

Alle rechten worbehouden. Niets uit deze uitgave mag worden wervelwoudigd, opgeslagen in een genutomatiseerd gegevensbestand, of openbarar gemaakt, in enige vorm of op enige wijze, hetzij elektronisch, mechanisch, door fotokopieen, opnamen of enige andere manier, zonder voorafgaande schriftelijke toestemming wan de uilgeverij.

Woor zover het maken van kopieen uit deze uitgave is toegestaan op grond wan art. $16 \mathrm{~b}$ Auteurswe1 1912 jo. het Besluit warl 20 juni 1974 , Stb. 351 , zoals gewijzigd bij Besluit van 23 augustus 1985 , $5 t b$. 471 . on art. 17 Auteurswet 1912, dient men de daarvoor wettelijk verschuldigde vergoedingen te voldoen an de Stichting Reprorecht (Postbus 882, 1180 AW Amstiveen). Voor het overnemen van gedeelte(n) uit dexe untgawe in bloemlezingen, readers en andere compilatiewerken (art. 16 Auteurswet 1912) dient men zich tor de uitgever to wenden.

No part of this book may be reproduced in any form, by print, photoprint, microfilm or any other means without written permission from the publisher. 
Mijh heer de rector magnificus,

Zeer gewaurdeende toehoorders,

\section{Inleiding}

Reeds kort na de verschrikkelijke cafébrand in Volendam begin van dit jaat, is een intensief onderzoek gestart naar de toedracht van de ramp: hoe heeft het zover kunnen komen? In eerste instantie trokken de verantwoordelijke autoriteiten naar buiten toe als een eenheid op. De eerste dagen werden er gezamenlijke persconferenties gehouden waarin uiteengezet werd hoe te werk zou worden gegaan bij de verdere afwikkeling. Naarmate meer feiten aan het licht traden, begon het gezamenlijke front echter barsten te vertonen. Bestuurders en ambtenaren traden afzonderlijk in de publiciteit. Op vrijdag 5 januari hield tot verrassing van de aanwezige journalisten de regionale brandweer eer eigen persconferentie waarin onvrede werd geuit over het feit dat het ontbreken van vluchtwegen na de brand zo veel aandacht trok. De werkelijke oorzaak was de gevaarlijke en verboden kerstversiering waartegen de gemeente verzuimd had op te treden, zo verklaarde cle brandweercommandant. De brandweer daarentegen trof geen enkele blaam. ${ }^{1}$

Op zondag 7 januari was het de beurt aan de burgemeester. In een televisieinterview verklaarde hij dat hij en zijn wethouders door de ambtenaar van brandpreventie onvoldoende over de gang van zaken bij de betrokken cafés waren geïnformeerd Dit werd de burgemeester in eigen kring kennelijk niet in dank afgenomen. Een dag later zag het college van B en W zich genoodzaakt een officiële verklaring uit te geven waarin het 'onvoorwaardelijke vertiouwen' in alle medewerkers van de gemeente werd uitgesproken. De burgemeester voegde daar aan toe zich niet te willen verschuilen achter een ambtenaar. In de verklaring werd nog eens dat het college de volledige politieke verantwoordelijkheid voor de gebrekkige controle op zich nam. ${ }^{2}$ Toen was ook reeds bekend dat burgemeester en wethouders op termijn zouden terugtreden.

Deze gebeurtenissen zijn een illustratie van het spanningsveld warin bestuurders en ambtenaren tegenwoordig terecht kunnen komen. Zeker voor ambtenaren is dit niet altijd zo geweest. Bijna vijfentwintig jaar geteden schreef W.J. van Eijkern - in die tijd hoofd van de toenmalige Stafafdeling Wetgeving Publiekrecht van het ministerie van Justitie - een opstel onder de titel 'De macht van de zwoegers in het vooronder. ${ }^{3}$ Daarmee doelde hij - de oorspronkelijke term is van oud-minister Van Agt - op de departementale wetgevingsambtenaren. Zij bleven als regel anoniem, zeker bij het grote publiek. "Hun arbeid mist de glans van de rechter of de bestuurder". Aldus Van Eijkern in 1977. Het roept het beeld

NRC Handelsblad 6 januari 2001.

NRC Handelsblad 9 januari 2001.

W. I. van Eijkem, De macht van de zwoegers in het vooronder, in: G.E. Langemeijer, H.Th.J.F. van Marseveen en J.M. Polak, De jurist-ambtenaar, Burdel opsteilen opgedragen aan J.M. Kan, Zwolle 1977, p. 39 e.v. Zie voorts A. Patijn, De wetgevingsambtenaar en de politiek, Regelmat 1988, $\beta .73$ e. 
op van de klassieke ambtenaar die verborgen onder de weugels van de politiek verantwoordelijke bestuurder, nagenoeg van de buitenwereld is afgesloten.

Dit beeld is allang geen werkelijkheid meer. De ambtelijke zwoegers zijn uit het vooronder omhooggestegen en staan nu niet zelden voor iedereen zichtbaar op het voordek. Een mooie illustratie daarvan is te vinden in het jongste jaarwerslag van de directie wetgeving van hetzelfde ministerie waar Van Eijkern ooit werkzaan was. Het oude beeld van de zwoeger in het vooronder wordt daarin uitdrukkelijk van de hand gewezen. "In werkelijkheid wordt wetgeving ontwikkeld in voortdurende samenspraak met een groot aantal actoren binnen, maar vooral ook buiten de rijksowerheid. Dat is nodig om de betrokken belangen in kaart te brengen en draagvlak voor het wetswoorstel te creëren maar vaak ook om in de samenleving aanwezige kennis te mobiliseren", aldus het jaarverslag. Overigens vornt het verslag reeds op zichzelf een duidelijk symptoom van deze ontwikkeling: het was vijfentwintig jaar geleden nog ondenkbaar dat een departementale afdeling met zoiets als een jaarverslag zelfstandig natar buiten zou treden. Thans is zulks gemeengoed.

In mijn rede will ik ingaan op de staatsrechtelijke gevolgen van deze ontwikkeling. Allereerst komt kort de formele positie van de ambtenaar en de ambtelijke dienst in het huidige staatsrechtelijke bestel aan bod (par. 2). Dit vormt als het ware het vertrekpunt voor de verdere gedachtevorming Vervolgens zal ik aandacht besteden aan de ministeriële verantwoordelijkheid voor de ambtelijke dienst en de recente ontwikkelingen die zich op dit punt hebben voorgedaan (par. 3 en 4). Beschouwingen daaromtrent kunnen moeilijk worden gemist vanwege de dominante rol die dit vraagstuk speelt binnen de politiek-ambtelijke verhoudingen van dit moment. Ten slotte zal ik een aantal basisvragen behandelen die met het oog op de toekomst voor deze verhoudingen van belang zijin (par. 5-11). Daarbij zal ik aandacht besteden aan de situatie in het Verenigd Koninkrijk, omdat daar het beginsel van de ministerièle verantwoordelijkheid eveneens een dominante rol speelt en zich in dat verband problemen hebben voorgedaan die tot op zekere hoogte vergelijkbaar zijn met die waarmee wij thans in Nederland worden geconfronteerd.

\section{De staatsrechitelijke positie wan de ambtenaar}

In het geldende staatsrecht is de ambtenaar althans formeel gesproken nauwelijks zichtbaar. De aandacht is vooral gericht op de politiek verantwoordelijke minister. ${ }^{5}$ De aan hem ondergeschikte organisatie blijft doorgaans buiten beeld: het betreft een interne aangelegenheid die de minister in beginsel naar eigen inzicht kan regelen. De Grondwet volstaat dan ook met een summiere bepaling. In artikel 44 , eerste lid, wordt slechts bepaald dat bij koninklijk besluit ministeries worden ingesteld welke onder leiding staan van een minister. Met het

5 Do positie van de stantssecretaris - geregeld in art. 46 Grw, - laat ik in dit verband buiten beschowwing. Zie echter par. 5 . 
begrip 'ministerie' wordt gedoeld op 'een onder directe verantwoordelijkheid van een minister staand onderdeel van de rijksdjenst". ${ }^{*}$ Hoeveel ministeries er zijn, op welke wijze zij moeten worden ingericht en welke regels behoren te gelden voor het functioneren van de departementale organisatie, laat het staatsrecht ongeregeld.

Pogingen om de grondwettelijke regeling van de ambtelijke organisatie op rijksniveau uit te breiden, zijn recentelijk gestrand. Het kabinet Kok I had voorgesteld artikel 134 Grondwet aan te vullen met een bepaling omtrent zelfstandige bestuursorganen. ${ }^{8}$ Onder druk van de Tweede Kamer - welke was voorafgegaan door een kritisch advies van de Raad van State - heeft de regering het daartoe bestemde wetswoorstel teruggenomen. De heterogeniteit en het ontbreken van zicht op hetgeen aan de vele in de praktijk reeds bestaande zelfstandige bestuursorganen gemeenschappelijk is, leidde uiteindelijk tot de slotsom dat de tijd voor grondwetswijziging nog niet rijp is. Wel is onlangs een voorstel voor een Kaderwet zelfstandige bestuursorganen bij de Tweede Kamer ingediend. ${ }^{10}$

In relatie tot de volksvertegenwoordiging is het alleen de minister en niet de ambtenaar die verantwoording aflegt. In de Grondwet komt dit het duidelijkst tot uitcrukking in artikel 68. Op grond hiervan zijn ministers en staatssecretarissen verplicht aan de Tweede en Eerste Kamer alle gevraagde inlichtingen te geven. Uit artikel 69 blijkt dat het ook de minister is die in het parlement verschijnt on aan de beraadslagingen deel te nemen. Indien hij door een van beide kamers wordt uitgenodigd om ter vergadering aanwezig te zijn, dient hij in beginsel daaraan gevolg te geven. Dit alles geldt niet voor de ambtenaar.

Wel bepaalt artikel 69 , derde lid, dat de ministers en de staatssecretarissen zich in beide Kamers kunnen doen bijstaan door de personen, daartoe door hen aangewezen. Met 'personen' wordt in dit verband hoofdzakelijk op ambtenaren gedoeld. " De bepaling laat er geen misverstand over bestaan dat niet de Tweede of Eerste Kamer bepaalt wie de minister zal vergezellen, maar de minister zelf. ${ }^{12}$

6 Kamerstukken II 1980-1981, 16035, nr. II, p. 5.

7 Dit laat onverlet dat er door de jaren heen wel uitvoerig is nagedacht over de bestuurlijke positic van de minisieries. Zie bijvoorbeeld hei rapport "Natr kerndepartementen, kiezen voor een hoogwaardige en flexibele rijksdienst', Kamerstukken II 1992-1993, 21427, nr. 51 (commissie-Wiegal), alsmedo de rapportage van de secretarissen-generaal, De organisatie en werkwijze van de rijksdiensi, Den Haag 1993. Zie voorts de ontwikkelingen en beleidsinitiatieven die zijn geschetst in de recente nota 'Vertrouwen in verantwoordelijkheid', aangeboden aan de Tweede Kamer per brief van 17 september 1999: Kamerstukken II 1999-2000, 26806, nr. I.

8 Kamerstukken II 1997-1998, 25629, nrs. 1-3.

9 Kamerstukken II 1997-1998, 25629, nr. 6. Zie ook het advies van de Raad van State: Kamerstukken II 1997-1998, 25629, B.

10 Kamerstukken II 2000-2001, 27426, nrs. 1-2.

11. Artikel 104, eerste lid, Grondwet 1972 bepalde nog dat de ministers zich kunnen laten bijstaan door 'mbtenaren'. Omdat de bijstand echter niet attijd wan ambtenaren afkomstig behoeft te zijn, is het begrip 'ambtenaren' vervangen door 'personen': Kamerstukken II 1976-1977, 14224, nr. 3, p. 7.

12 Een belangrijke uitzondering vormt de parlementaire enquête. Ambtenaren zijn ingevolge artikel 3 van de Wet op de Parlementaire Enquête verplicht om te voldoen 
Het Reglement van Orde van de Tweede Kamer sluit daarbij aan. Artikel 42 bepaalt dat ambtenaren in een mondeling overleg met een kamercommissie met instemming van de desbetreffende minister inlichtingen kumnen verschaffen. ${ }^{13}$

Deze lin wordt op strikte wijze doorgetrokken in de Aanwijzingen inzake exteme contacten van rijksambtenaren. ${ }^{14}$ Hierin is nog eens met zoveel woorden vastgelegd dat de minister het door een van beide Kamers gevraagde contact met een bepaalde ambtenaar kan weigeren. Contacten tussen de Kamers en ambtenaren in persoon dienen zoveel mogelijk in aanwezigheid van de minister te verlopen. Bovendien dienen ambtenaren zich tijdens deze contacten te beperken tot het verstrekken van informatie van feitelijke aard. Zij leggen geen verantwoording af over het gevoerde beleid en magen geen persoonlijke beleidsopvattingen uitdragen.

In de grondwettelijke bepalingen die tot dusverre aan de orde zijn geweest, wordt de ambtenaar niet met zoveel woorden genoemd. Dit is wel het geval in artikel 109. Dit artikel draagt de wetgever op regels te stellen omtrent de rechtspositie van ambtenaren. Deze zijn neergelegd in de Ambtenarenwet 1929 en de daarop gebaseerde regelgeving. Zij hebben hoofdzakelijk betrekking op de arbeidsverhouding tussen ambtenaar en bevoegd gezag en de rechtspositionele rechten en plichten die in die verhouding gelden. Voor de staatsrechtelijke positie van de ambtenaar zijn zij doorgaans van minder groot belang.

Een belangrijke uitzondering hierop zijn de grondrechtelijke bepalingen (art. 125 a e.v.). Deze zijn in de Ambtenarenwet opgenomen na de grondwetsherziening van $1983 .{ }^{15} \mathrm{Bij}$ die gelegenheid is erkend 'dat de grondwettelijke grondrechten voor een ieder gelden, ongeacht zijn verhouding tot de overheid, zodat

aan cle oproep van de daartoe ingestelde commissie om te worden gehoord. Zij kumen zich evernwel verschonen indien het verschafien van de gewaagde inlichtingen in strijd zou zijn met het belang van de staat. De gegrondheid van de door de ambtenaar ingebrachte verschoning dient eventueel door de desbetreffende minister te worden bevestigd. Zie artikel 20 , tweede en derde lid.

13 De contacten tussen Tweede Kamer en ambtenaren zijhn reeds in de zeventiger en tachtiger , jaren onderwerp van discussie geweest. Zie voor een overzicht: J.A.B. Janus, Ambtelijke bijstand, informatie en werantwoording, in: Gegeven de Grondwet (C2W-bundel), Deventer 1988, p. $105 \mathrm{e}, w$. Met name kan worden gewezen op het mar aanleiding wan de RSV-enquette opgestelde rapport van de bijzondere Commissic voor Onderzoek van de organusatie en de werkwijze der Kamer (commissieDolman), Kamerstukken II 1985-1986, 19336, nrs. 1-2, p. 12 e.v. en het kabinetsstududpun terzake: Kamerstukken II 1985-1986, 19336, ar. 5, p. 5. Nar tanleiding hiervan is een weetat artikelen het $\mathbb{R}$ wOTK opgenomen waarvan de strekking overeenkwam met het huidige artikel 42. Zie verder artikel 29, tweede lid, RvOTK dat de mogelijkheid biedt woor een kamercommissie om rijksambtenaren te horen en hen dartoe uit te nodigen door tussenkomst van de desbetreffende minister.

14 Besluit van de minister-president d.d. 19 mei 1998, Stcrt. 1998, nr. 104. Zie met name de aanwijzingen $3-5$.

15 Wet wan 20 april $1988, \mathrm{Stb}, 1988,229$. Zie woor een algemene toelichting hierop: Kamerstukken II 1986-1986, 19495, nr. 3. Een zelfde wijziging is in de Militaire Ambtenarenwet opgenomen bij de Wet wan 20 april 1988, Stb. 1988, 288. Zie artikel $12 \mathrm{ac} . \mathrm{v}$ 
ook de ambtenaar zich erop kan beroepen. ${ }^{15}$ Men is in de huidige tijd geneigd te vergeten dat dit niet altijd als vanzelfsprekend is ervaren. In de eerste helft van de twintigste eeuw was zelfs de heersende opvatting dat de uitoefening van grondrechten door ambtenaren zich niet goed werdraagt met het goed functioneren van de openbare dienst. ${ }^{17}$ Ambtenaren behoren dienstbaar te zijn aan de publieke zaak en derhalve objectief en politiek neutraal te opereren, zo was de oorspronkelijke gedachte. In deze taakopvatting was voor grondrechten van ambtenaren geen plaats. ${ }^{18}$

Pas na de tweede wereldoorlog is hierin geleidelijk aan verandering gekomen. ${ }^{19}$ De discussie spitste zich daarbij vooral toe op de vrijheid van meningsuiting: met betrekking tot dit grondrecht doen zich ook de scherpste dilemma's voor. Als hoofdregel gold aanvankelijk dat geen beperkingen van do vrijheid van meningsuiting waren toegestaan dan die welke voortvloeien uit de algemene eis van ambtelijke loyaliteit. ${ }^{20}$ Deze eis is nog betrekkelijk streng: loyaliteit veronderstelt positieve ondersteuning van het overheidsbeleid. Later is de ruimte voor ambtelijke meningsuitingen in de jurisprudentie verder uitgebreid. Vanaf de tachtiger jaren paste de Centrale Raad van Beroep als norm toe dat de ambtenaar zich diende te onthouden van negatieve uitingen, dat wil zeggen uitingen die het goed functioneren van de openbare dienst in ontoelaatbare mate zouden kunnen aantasten. ${ }^{21}$

In 1988 is de jurisprudentiële norm in de Ambtenarenwet gecodificeerd. Artikel 125 a bepaalt dat de ambtenaar zich dient te onthouden van uitingen ${ }^{22}$ indien hierdoor 'de goede vervulling van zijn functie of de goede functionering van de openbare dienst, voor zover deze in verband staat met zijn functievervulling, niet in redelijkheid zou zijn verzekerd'. ${ }^{23}$ Deze wettelijke verankering heeft niet aan alle onzekerheid een einde gemaakt. De beperkingsnorm is zodanig algemeen dat deze in de praktijk tal van vragen oproept. Om die reden worden in de al eerder

16 Kamerstukken II 1975-1976, 13872, nr. 3, p. 11.

I.7 CRvB 6 april 1939, AB 1939, p. 690 .

18 Deze opvatting wordt ook thans nog door een enkeling verdedigd. Zie P.B. Cliteur, 'Ambtenaar moet zwijgen en dienen', NRC Handelsblad 20 oktober 1998 met een weerwoord van J.J. Stam in NRC Handelsblad 27 oktober 1998.

19 Voor een historisch overzicht zij verwezen nar C.J.G. Olde Kalter, Overheidspersoneel en grondrechten, Preadwies VAR Zwolle 1979 en M.C. Burkens, Algemene leerstukken nat Nederlands constitutioneel rech, 2 wolle 1989, p. 193 e.w.

20 Aanwijzingen nzake ambtelijk optreden, betrekking hebbend op de vrijheid van meningsiting wan burgerlijko anbienaren, Stert. 1972, 152.

21 CRvB 3 januari 1985, TAR 1985, 59. De kentering in de opstelling van de Centrale Raad was eerder in de jurisprudentie zichtbaar. Zie CRwB 21 september $1979, \mathrm{AB}$ 1980, 90 (Kaima).

22 Het begrip 'uitingen' dient hier ruim te worden werstan. Artikel $125 \mathrm{a}$, eerste lid, spreekt over 'het onthouden wan het openbaren van gedachten of gevoelens of van de witoefening van het recht tot vereniging, tot vergadering en tot betoging'. Aldus gelidt dezelfde norm voor alle politieke grondrechten, zoals vastgelegd in do antikelen 7,8 en 9 Grondwet.

23 De rechter toetst kritisch an deze nom. Een te algemeen verbod tot het doen wan uitlatingen sneuvelde in Pres. Rb. Utrecht 24 februari 1999, JB 1999, 94 m.n. G.J.J. Heema van Voss (De KwaadstenietRIVM). 
genoemde ambtelijke aanwijzingen enkele factoren genoemd die een rol kunnen spelen bij de beoordeling of de norm van artikel 125a Ambtenarenwet is overschreden. ${ }^{2 / 3}$ Deze opsomming beoogt voor de praktijk enig houvast te bieden.

\section{De factoren waar het hier om gaat, zijn:}

a. de afsiand lussen de functie van de betrokken ambtenaar en het beleidsterrein waarover de vitlatingen zijn gedaan;

b. de politieke gevoeligheid van de materie;

c. het tijdstip wastop de uitspraken worden gedaan;

d. de voorzienbaarheid van de schadelijkheid ten tijde van de uitspraken;

c. de ernst en de duur van de door de uitspraken ontstane problemen voor de dienstvervulling van de betrokken amblenaar of het functioneren wan de openbare dienst, voor zover deze in verband staat met diens dienstvervulling.

De opsomming is niet limitatief. De onder a genoemde factor lijkt enigszins zwaarder te wegen dan de andere factoren gezien de in de toelichting vervatte interpretatie dat 'indien de ambtenaar onder de weraintwoordelijkheid van de minister walt en diens beleid aanvalt, maar met het desbetreffende beleidsterrein in zijn hoedanigheid wan ambtenaar geen enkcle bemoejenis heeft, voor wat zijn recht op vrijheid wan meningsuiting betreft geen andere beperking gelde dan die voor iedere andere burger geldt'. In de hier beschreven situatie leggen de onder b tot en met e genoemde factoren kennelijk geen gewicht meer in de schaal.

Opvallend is dat de Straatsburgse jurisprudentie ambtenaren aanmerkelijk minder bescherming biedt. Weliswaar heeft het Hof als algemeen principe erkend dat de rechten zoals vastgelegd in het EVRM ook gelden voor ambtenaren, ${ }^{25}$ maar de beperkingen die het Hof tot dusverre toelaatbaar heeft geacht, gaan verder dan wij in Nederland zouden accepteren. In het recente arrest Ahmed vs. UK oordeelde het Hof de Britse regells die de politieke activiteiten van gemeenteambtenaren vergaand aan banden leggen, in overeenstemming met artikel 10 EVRM. ${ }^{26}$ Volgens het Hof kunnen dergelijke regels als noodzakelijk in een democratische samenleving worden beschouwd om de politieke neutraliteit en loyaliteit van ambtenaren te waarborgen. Het waarborgen van de loyaliteit speelde eveneens een rol in de argumentatie van het Hof in het arrest Pellegrin vs. France. Hierin oordeelde het Hof dat artikel 6 EVRM niet van toepassing is op geschillen tussen ambtenaren on de overheid als werkgever voorzover de betrokken ambtenaar belast is met de uitvoering wan - hetgeen ik kortheidshalve benoem als - de 'echte' overheidstaken. ${ }^{27}$ Daarmee worden substantiële catego-

24 Besluit van de minister-president d. 19 mei 1998, Stcrt. 1998, nr. 104 (Aanwizing 15).

25 EHRM 28 augustus 1986, NI1987,943 m.n. EAA, NJCM-Bull. 1987, p. 235 e.v. m.n. L. Zwak en I. Boerefin (Kosiek en Glasenapp). Later opnieuw bevestigd in EHRM 26 september 1995, NI 1996, $545 \mathrm{~m}, \mathrm{n}$. EJD, N.CM-Bull. 1996, p. 523 a.v. M.n. J.A. Holiman (Vogt).

26 EHRM 2 september 1998, NJCM-Bull. 1999, p. 946 e.v. m.r. R. Niessen. Zie voorts EHRM 20 mi 1999. NJCM-Bull. 1999, p. 962 e.w. m.n. A.J. Nieumenhuis (Rekvenyi).

27 EHRM 8 december 1999. AB 2000, 195 m.n. LV. Het Hof oordeelde dat artikel 6 niet geldt voor ambtenaren "whose duties typify the specific activities of the public service in so far as the later is acting as the depositary of public authority respon- 
rieên ambtenaren beroofd van hun recht om een geschil met hun werkgever voor te leggen aan de onafhankelijke, onpartijdige rechter. Deze jurisprudentie is hoogst ongelukkig. Niet valt in te zien waarom de specifieke positie van ambtenaren zou nopen tot zulke vergaande beperkingen van hun techtsbescherming tegen rechtspositionele besluiten.

Resumerend kan worden gesteld dat de staatsrechtelijke positie van de ambrenaar wordt gekenmerkt door onzelfstandigheid. ${ }^{28}$ Hij is hiêrarchisch ondergeschikt aan de minister en heeft in die positie meestal ${ }^{29}$ geen zelfstandige bevoegdheden en ook geen externe verantwoordingsplicht. De grondwettelijke en verdragsrechtelijke erkenning dat ook ambtenaren over grondrechten beschikken, heeft in deze situatie geen wezenlijke verandering gebracht. Deze rechten mogen worden beperkt voorzover het goed functioneren van de openbare dienst door de grondrechtsuitoefening zou kunnen worden aangetast.

\section{De ministeriële verantwoordelijkheid: aangrijpingspunt voor controle}

De onzelfstandige positie van de ambtenaar hangt nauw samen met de politieke ministeriële verantwoordelijkheid. Deze vind: zijn oorsprong in de negentiende eeuw, maar neemt in ons huidige staatsrechtelijke bestel nog steeds een centrale plaats in. ${ }^{30}$ Tot 1840 waren ministers uitvoerders van de bevelen van de Koning en waren zij ook alleen aan hem verantwoording schuldig. Invoering van de ministeriële verantwoordelijkheid betekende in wezen dat de ministers zich moesten 'omdraaien'. ${ }^{31}$ Ministers waren niet langer dienaren des Konings, maar dienaren van de Staten-Generaal. Zij konden zich niet meer verschuilen achter de bevelen van de Koning, maar waren voor alle regeringsdaden rechtstreeks ver-

sible for protecting the general interests of the State or of other public authorities" (r.0. 33). Later bevestigd in EHRM 27 juni 2000, EHRC 2000, 67 m.n. A.W. Heringa (Frydlender).

28 Th.C. de Graaf, Ambtenaar, minister en volksvertegenwoordiging, in: Nijmeegs staatsrecht (Beekrnan-bundel), Nijonegen 1987 , p. 36.

29 Buiten beschouwing laat ik de ambtenten atn wie de wetgever bewoegdheden heef geattribucerd, zoals de Inspecteur uer Belastingen. Voorzover her gaal om departementsambtenaren ga ik er van uit dat ondanks de atributie de ministeriele verant woordelijkheid voor handelingen wain de betrokken artatenaren volledig is. Zic voorts het Voorontwerp Algemene wet besturstecht, Vierde Tranche, Den Haag 1999 wasin door de Commissie wetgeving algenene regels van bestuursecht wordt voorgesteld enkele bepalingen omtrent atributie in de $A$ wb op to nemen (afdeling $10.1 .3 \mathrm{j}$

30 Zie voor een historisch overzicht: A.H.M. Dolle, De geschiedenis wan de Nederlandse ministeriele verantwoordelijkheid op hoofdijnen: in: D.J. Elzinga (red.), Ministeriele verantwoordelijkheid in Nedertand, Zwolle 1994, p. I e.v. en J.Th.J. van den Berg. Ministeride verantwoordelijkheid: "De zweepslag voor de ambtelijke dienst', Socialisme en democratie 1989 , p. 119 e.v.

31 Steekhoudend ministerschap. Rapport wan de externe commissie Ministerite Verantwoordelijkheid (commissie-Scheltema), Kamerstukken II 1992-1993, 21427, nrs. $40-41$, p. 7 . 
antwoording schuldig aan de volksvertegenwoordiging. Het was voortaan juist de Koning die politiek gesproken buiten schot bleef. We treffen de essentie van deze historische ontwikkeling nog steeds aan in onze Grondwet. Artikel 42, tweede lid, bepaalt: de Koning is onschendbaar; de ministers zijn verantwoordelijk.

De ongewijzigde redactie van de Grondwet laat onverlet dat sinds de negentiende eeuw het leerstuk van de ministerielle verantwoordelijkheid in de praktijk een andere betekenis heeft gekregen. Ging het vroeger om de vraag aan wie ministers verantwoording verschuldigd zijn, in de tegenwoordige tijd gaat de aandacht vooral uit naar de wijze waarop verantwoording moet worden afgelegd over het handelen van de ambtelijke dienst. Gezien de maatschappelijke ontwikkelingen ligt deze verschuiving voor de hand. De bemoeienis van de overheid met het maatschappelijk leven is sinds het ontstaan van ons parlementaire stelsel sterk toegenomen. Dit is gepaard gegaan met het ontstaan van een omvangrijk ambtelijk apparaat. Als we het in deze tijd hebben over regeringshandelingen, gaat het veelal niet meer om persoonlijke handelingen van de Koning of van een of meer ministers, maar om handelingen die feitelijk door ambtenaren worden verricht.

De functie van de ministeriële verantwoordelijkheid is hierdoor een wezenlijk andere geworden. Zij fungeert thans in de eerste plaats als centraal aangrijpingspunt voor democratische controle op het handelen van - in beginse $\left.\right|^{32}-$ de gehele ambtelijke dienst. In de kern gaat het - volgens Burkens - om het zodanig organiseren van de overheidsmacht dat deze als bevoegdheid wordt gestructureerd zodat deze beheersbaar wordt gemaakt en vervolgens onder de controle van de volksvertegenwoordiging wordt geplaatst. Daarvoor is nodig dat de diffuse macht van de ambtelijke dienst grijpbaar wordt gemaakt door deze integraal toe te rekenen aan een ambt dat verantwoordelijk kan worden gehouden, te weten de minister ${ }^{33}$ De minister vormt aldus het scharnierpunt ${ }^{34}$ voor parlementaire controle: hij is de enige die door het parlement op het optreden van de ambtelijke dienst kan worden aangesproken.

Wat betekent nu het afleggen van verantwoording? Als we kijken naar de parlementaire praktijk betekent het eerst en vooral het verstrekken van inlichtingen. Ministers dienen dagelijks vele vragen van kamerleden te beantwoorden. Deze zijn veelal van feitelijke aard. Maar de ministeriële verantwoordelijkheid omvat weel meer. Het afleggen van verantwoording impliceert tevens het uitleggen, motiveren en verdedigen van gevoerd beleid. ${ }^{35}$ De minister neemt in beginsel alle ambtelijke handelingen die zijn verricht en alle besluiten die binnen zijn departement genomen zijn, voor zijn rekening.

32 Op de positie van zelfstandige bestuursorganen kom ik hiema nog terug. Zie par. 5.

33 M.C. Burkers, in: Ambtenaar, dienaar van de minister? Verslag van het symposium over de positie en de macht van de anbtenaar d.d. 28 augustus 1986 , ter gelegenheid van het vertrek van me. Gritter als chef van de Stafafdeling Constitutionele Zaken en Watgevingsaangelegenheden wan het Ministerie wan Binnenlandse Zaken, Den Haag 1986. p. 9.

34 Steokhoudend ministerschap, a.w., p. 8 .

35 ldem. 
Juist vanwege deze ruime verantwoordingsplicht is de ministeriele verantwoordelijkheid de latste decennia onder toenemende spanning komen te staan. In de literatuur is de ministerielle verantwoordelijkheid wel aangeduid als een fictie. De staatsrechtelijke norm van volledige pollitieke verantwoordelijkheid zou volgens deze opvatting geen recht meer doen aan de werkelijkheid. De feitelijke mogelijkheden van een minister om invloed uit te oefenen op de gang van zaken binnen een omvangrijke departementale organisatie, zijn beperkt. Om die reden zou het volgens de desbetreffende auteurs niet redelijk zijn ambtelijk falen voor rekening te laten komen van een minister voor zover hem terzake geen enkel persoonlijk verwijt treft. De omvang van de ministeriële verantwoordelijkheid zou dienovereenkomstig moeten worden beperkt, zo was de gedachte. ${ }^{36}$

Deze verwijtbaarheidsdoctrine is door anderen krachtig bestreden. ${ }^{37}$ Veel staatsrechtelijke auteurs hebben benadrukt dat de ministerielle verantwoordelijkheid onaangetast moet blijven om het parlement te allen tijde de mogelijkheid te bieden de minister ter verantwoording te roepen. Dit dwingt de minister ertoe greep te houden op het ambtelijk apparaat. ${ }^{38}$ Wordt de ministeriêle verantwoordelijkheid beperkt tot hetgeen de minister persoonlijk kan worden aangerekend, dan kan deze ontvankelijk worden woor de neiging om zich afzijdig te houden of niet te zeer aan te dringen om zich goed door zijn ambtenaren te laten voor lichten. De positie van het parlement zou hierdoor worden werzwakt.

Over de afwijzing van de verwijtbaarheidsdoctrine lijkt nu althans op het eerste gezicht een redelijke mate van consensus te bestaan. Dat is met name het gevolg van het in 1993 verschenen rapport Steekhoudend ministerschap van de commissie-Scheltema. Dit rapport - geschreven op verzoek van de Tweede Kamer in het kader van de operatie Staatkundige, bestuurlijke en staatsrechtelijke vernieuwing - biedt een heldere analyse van de belangrijkste aspecten van de ministeriële verantwoordelijkheid, die tot op heden een belangrijke leidraad vormt. Na dit rapport wordt algemeen aanvaard dat de omvang van de ministeriële verantwoordelijkheid voor de ambtelijke dienst niet door feitelijke, maar door juridische criteria wordt bepaald. ${ }^{39}$ De minister is politiek verantwoordelijk voor zover hij beschikt over formele bevoegdheden om het handelen van de overheidsorganisatie te beïnvloeden Voor zover het gaat om het functioneren van

36 Zie bijvoorbeeld F.A.M. Stroink, Het leerstuk der deconcentratie, Den Haag 1978, p. 141. M. Scheltema, H.G. Lubberdink, Ministertele werantwoordelijkheid en parlementaire controle, Preadvies statatsrechtconferentie 1980 , Utrecht $1980,0,1-18, \mathrm{H}$. van Mararseven, Reidans der niet-verantwoordelijken, NJB $1987, p .1516, \mathrm{M}$. Tuurenhout, Parlementaire controle en amblelijke verantwoordelijkheid, Amhem 1992, p. 39. Zie voor een overzicht met literatuurverwijzingen: D.J. Elzinga, De doctrine van de politieke en ministeriele verantwoordelijkheid, in: De stat van het recht. Opstellen over statisrecht en politick, Zwolle 1990, p. 92 e., m.n. p. $105 \mathrm{c}$.

37 Zie onder meer M.C. Burkens, w., p. 19,20, A.M. Donner, Verantwoordelijkheid, Themis 1987, p. 365 e.v. C.A.I.M. Kormann, De grondwetsherzieningen 1983 en 1987, Deventer 1987, p. 173, 174, D.l. Elxinga, a.w. p. $1 \| 1$ e.w.

38 M.C. Burkens, a.w., p. 20.

39 Steekhoudend ministerschap, a.w, p. 13, 14. Later bevestigd door de Tweede Kaner door het aannemen van de motie-Jurgens e.a. (Kamerstukken II 1993-1994, 21427, vir. 69). 
het onder hem ressonterende departement is deze verantwoordelijkeid volledig: Zuj is net beperkt tot hetgeen de minister persoonlijk kan worden aangerekend.

\section{De ministerielle verantwoordelijkheid: recente ontwikkelingen}

Ruim acht jaar na verschijning wan het rapport 'Steekhoudend ministerschap' moet worden wastgesteld dat de toen gevoerde discussie minder duidelijkheid heeft gegeven dan wellicht oorspronkelik werd gedacht. Het debat over de ministeriele vermontwoordeligheid voor de ambtelike drenst is niet geluwd. Integendeel, de gebeurtenissen gedurende de huidige kabinetsperiode wijzen erop dat de spanningen in de politick-ambtelijke verhoudingen verder zijn toegenomen. De ininisteriele verantwoordelijkheid als statsrechtelijk leerstuk is in die contex opnieuw in discussie gekomen.

De enquête van de Tweede Kamer naar de vliegramp in de Bijlmermeer heeft daarbij een belangrijke rol gespeeld. Tijdens de verhoren van de enquêtecommissie in 1999 is naar woren gekomen dat bepaalde owerheidsfunctionarissen relevante informatie over de lading van het vliegtuig - welke informatie overigens achteraf gezien onjuist bleek - 'onder de pet' hebben gehouden." Hoewel het hier een incidentele gebeurtenis betrof, is mede door de overvloedige publiciteit het beeld ontstaan van ambtenaren die stelselmatig verzumen hun minister te informeren. De enquêtecommissie toonde zich "buitengewoon verontnust' over dit verschijnsel en kwam met de aanbeveling dat het voorgenomen integriteitbeleid bij de overheid met voortvarendheid moet worden uitgevoerd. Daarenboven meende zij dat de Tweede Kamer de mogelijkheid moet krijgen om

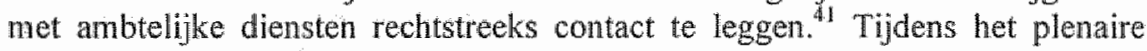
debat in de Tweede Kamer over het enquêterapport is uitvoerig over deze onderwerpen gesproken en in het bredere verband geplaatst van de ministeriele verantwoordelijkheid. Een aantal woordvoerders drong er op aan om mede tegen de achtergrond van de ministerielle verantwoordelijkheid, het functioneren van het openbaar bestuur opnieuw onder de loep te nemen. ${ }^{42}$

Kort daarua bleek dat er binnen de ragering verschillend over de inhoud van de ministeriele verantwoordelijkheid werd gedacht. In de zomer van $1999 \mathrm{kwam}$ een essay van de toenmalige minister Peper - oorspronkellik bestemd voor zijn collega-bewindslieden - in de openbarheid warin hij de vraag stelde of ten wanzien van de minusteriele verantwoordelikheid niet een nieuwe invulling of benadering kan worden ontwikkeld. Hij pleitte in dit verband voor aanvaarding van een 'foutenmarge". Het politieke debat zou naar zijn mening 'niet zozeer over de verantwoordelijkheid woor min of meer incidentele fouten moeten gaan, maar over de marge die als acceptabel wordt ervaren en over de wrag of

40 Kanerstukken $111998-1999.26241$, nrs. $8-9$, p. $385,386$.

41 Kamerstukken II 1998-1999, 26241, ns, 8-9, p. 402 en 405. Zie in dezelfde zin het rappont wan de commissie-Bakker omtrent vredesoperaties: Kamerstukken II 19992000,26454, nrs. $7-8$, p. 495 .

42 Zie vooral Handelingen II 1998-1999, p. 4727 e.v. Het antwoord van de regering is te vinden onder Hand II 1998-1999, p. 4787 ew. 
bepaalde zaken al dan niet die discretionaire ruinte van de ministeriele verantwoordelijkheid te buiten gaan: ${ }^{45}$ In dezelfde periode lekte een eerdere notitie uit van de toenmalige Secretaris-Generaal van het ministerie van Algemene Zaken die in dezelfde richting leek te gaan. Om te voorkomen dat het leerstuk van de individuele ministeriële verantwoordelijkheid zodanig wordt opgerekt dat titvoeringsincidenten aanleiding geven tot het stellen van de vertrouwenskwestie diende volgens de desbetreffende ambtenaar" te worden gekomen tot "een scherpere afbakening van de politieke verantwoordelijkheid en de ambtelijke verantwoordelijkheid voor de uitvoering'. ${ }^{4}$

Ten slotte wijs tk op het voorstel dat recentelijk is gedaan door de Wetenschappelijke Raad voor het Regeringsbeleid (WRR). In zijn vorig jaar verschenen rapport 'Het borgen van publiek belang ${ }^{145}$ stelt de Raad vast dat de ministeriêle verantwoordelijkheid als middel om het goed functioneren van de overheidsorganisatie te controleren, minder geschikt is. De Raad doet het voorstel tot instelling van een onafhankelijke instelling die de kwaliteit van de ambtelijke organisatie moet gaan beoordelen: de Kwaliteitskamer. Ook wordt in het rapport vergroting van de verantwoordelijkheden van ambtelijke diensten en van individuele ambtenaren bepleit. Dit laatste sluit aan bij hernieuwde pleidooien afkomstig uit bestuurskundige kring om ambtenaren zich publiekelijk te laten verantwoorden. ${ }^{46}$

De huidige regering heeft in reactie op deze ontwikkelingen steeds de onverkorte handhaving van de ministeriele verantwoordelijkheid voorop gesteld. ${ }^{47}$ Well meende zij dat behoefte bestond aan verheldering van de praktische invulling daarvan. In de in 1999 uitgebrachte nota "Vertrouwen in verantwoordelijkheid" geeft zij aan hoe het effectueren van de ministeriële verantwoordelijkheid kan worden verbeterd.

43 B. Peper, Op zoek naar samenhang en richting. Een essay over de veranderendo verhoudingen tussen overheid en samenleving, Socialisme en democratie $1999, \mathrm{p}$. 388 e.v., m.n. p. $396,397$.

44 Kamerstukken II 1998-1999, 26200 III, nr. 12, p. 5. De minister-president stelt zich in de begeleidende brief op het standpunt dat de notitio van zijn secretaris-generat "de ministerièle werantwoordelijkheid in geen enkel opzicht, laat staan in beperkende zin, in het geding brengl' (Kamerstukken II 1998-1999, 26200 III, in. 12, p. 2). Naar mijn mening kan de notitie ook anders worden gelezen.

45 WRR, Het borgen van publick belang, Den Hadg 2000. Een witwerking met het oog op de ministeriete verantwoordelijkheid is te vinden bij $\mathbb{M}$. Scheltema (thang voorzitter valn de WRR), Voldoet de ministeride verantwoordelikkeid nog bij een professionele overheidsorganisatie?, NJB 2000, p. 1861 e.v. Zie ook de reaclie van A.W. Heringa, Ministeriale verantwoordelijkheid en scheiding van machten, NJS 2000, p. 2129 e. $w$. met het naschrift wan Scheltema.

46. H. van den Heuvel, Ministeride verantwoordelijkheid in volle omvang, Openbaar bestuur 1999, nrs. 6/7, p. 2 e.y., M.A.P. Bovens, De vierde macht revisited Over ambtelije macht en publieke verantwoording (oratie UU, gehouden op 13 september 2000), www.usg.nl/oratie-mark-bovens html (latst bezocht op 3 januari 2001).

47 Kamerstukken II 1998-1999, 26200 III, n. 12, p. 1. Bevestigd in de kort duarna verschenen nota "Vertrouwen in verantwoordelijkheid", a.w., p. 1 . 
Een belangrijke prioriteit van de regering is de verbetering vain de professionaliteit en de integriteit van ambtenaren. ${ }^{4}$ De achitergrond daarvan wordt mede gevormd door ingrijpende veranderingen van het ambtelijk functioneren. De moderne overheid kan volgens de regering niet meer volstaan met verticaal en hiërarchisch ingerichte organisatievormen. De moderne ambtenaar neemt actief deel aan maatschappelijke verhoudingen die zijn 'gehorizontaliseerd'; hij opereert in complexe "netwerken" waarin "interactief" wordt samengewerkt. Met andere woorden: de ambtenaar als 'zwoeger' in thet wooronder' is een gepasseerd station. In het licht van deze veranderingen worden volgens de regering met het oog op de benodigde professionaliteit en integriteit andere eisen aan de ambtenaar gesteld dan vroeger het geval was. Deze eisen zouden deels in wettelijke regels moeten worden vastgelegd. Een nieuwe gemoderniseerde Ambtenarenwet zou de basis kunnen worden voor een set van rechten en plichten die voor alle ambtenaren zullen gelden. ${ }^{49}$

Resumerend moet worden vastgesteld dat de ministeriële werantwoordelijkheid de latatste decennia bij voortduring ter discussie staat. Pogingen om helderheid te verkrijgen - onder meer door het rapport Steekhoudend ministerschap - zijn slechts gedeeltelijk geslaagd. Steeds opnieuw laait het debat op.

Hoe nu verder? Het lijkt erop dat de basisvragen omtrent het functioneren van politiek-ambtelijke verhoudingen grotendeels dezelfde zijn gebleven. Nieuwe ontwikkelingen brengen hooguit accentverschillen in de vraagstelling teweeg. Gelet op de recente discussie, zijn de belangrijkste vragen naar mijn mening de volgende:

- Moet de omvang van de ministeriële verantwoordelijkheid worden beperkt in verband met de veranderende rol van ambtenaren en ambtelijke diensten binnen de rijksdienst?

- Zijn uit de ministeriele verantwoordelijkheid concrete spelregels te destilleren die zouden moeten gelden in de verhouding tussen minister en ambtenaar en zo ja, zijn deze thans voldoende geëxpliciteerd?

- Zijn de bestaande mogelijkheden voor contacten tussen de Tweede Kamer en ambtenaren toereikend en zo nee, in welke zin behoeven zij aanpassing?

- Welke rol speelt de Tweede Kamer in het algemeen als het gaat om de controle op het functioneren van de ambtelijke dienst?

Bij de behandeling van deze vragen zal ik aandacht besteden aan de wijze waarop dergelijke problemen in het Verenigd Koninkrijk worden benaderd om na te gaan of dit voor Nederland bruikbare gezichtspunten oplevert.

48 Vertrouwen in verantwoordelijkheid, p. $12 \mathrm{e} . \mathrm{v}$. en $32 \mathrm{e} . \mathrm{v}$. Over dit onderwerp heeft de regering en atzonderlijke nota 'Integriteit wan het openbaar bestuur' uitgebracht, welke eveneens op 17 september 1999 ann de Tweede Kamer is angeboden. Zite Kamerstukken II 1999-2000, 26806, nr. 1.

Vertrouwen in werantwoordelijkheid, a.w., p. 42. 


\section{Moet de ministeriële verantwoordelijkheid worden beperkt?}

Deze vraag leidt in de discussie tussen wetenschappers van verschillende dïsciplines tot een merkwaardige patstelling. Grofweg gesteld zijn er twee kampen. Enerzijds zijn er degenen - veelal staatsreclitbeoefenaren - die menen dat de ministeriele verantwoordelijkheid voor de ambtelijke dienst geen wijziging behoeft. ${ }^{50}$ Beperking van de ministeriële verantwoordelijkheid leidt in hun visie tot een ongewenste aantasting van ons parlementair stelsel. Anderen daarentegen - vaak te vinden onder bestuurskundigen en politicologen - zijn van oordeel dat het openbaar bestuur sinds het ontstaan van de ministeriale verantwoordelijkheid in de negentiende eeuw zodanig ingrijpend is gewijzigd, dat aarpassingen onvermijdelijk zijn geworden. Dit zou bijvoorbeeld kunnen geschieden door ambtenaren zelf aan het parlement verantwoording te laten afleggen ${ }^{31}$ of door ambtelijke diensten om te vormen tot zelfstandige bestuursorganen. ${ }^{52}$ Het eerste is tot dusverre niet verwezenlijkt, het laatste tot op zekere hoogte wel.

In het Verenigd Koninkrijk doen zich vergelijkbare dilemma's voor, maar opvallend is dat de oplossing daar vaak niet gezocht wordt in een beperking van de omvang van de ministeriêle verantwoordelijkheid. Er is een levendige discussie over de contacten tussen ambtenaren en parlement, maar een zelfstandige verantwoordingsplicht in staatsrechtelijke zin wordt niet gezien als een reêle optie. Ook bestuurlijke verzelfstandigingen leiden meestal niet tot een formele beperking van ministeriële bevoegdheden. In het Verenigd Koninkrijk bestaat een groot aantal, soms omvangrijke 'executive agencies". ${ }^{5.3}$ Anders dan de

50 Zie de literatuur genoemd onder noot 37. Zie voorts R.J. Hoekstra, De ministeriele verantwoordelijkheid, in: Gegeven de Grondwet (CZW-bundel), Deventer 1988, p. 95 e.v., H.R.B.M. Kummeling. Het primaat van de politiek en bestuur (Preadvies staatsrechtconferentie 1999), Deventer 2000, p. 25 e.v.

51 Onder meer bepleit door H.Th.J.F. van Maarseveen, in: Ambtenaar, dienaar van de minister? Verslag van het symposium over de positie en de macht van de ambtenatar dd. 28 augustus 1986, ter gelegenheid van het vertrek wan mr. Gritter als chef van de Stafafdeling Constitutionele Zaken en Wetgevingsiangelegenhaden van het Minisw terie van Binnenlandse Zaken, Den Flagg 1986, p. 11, 12 en 21 e.v., Th. C. de Grad, Ambtenaar, minister en volkswertegenwoordiging, in: Nijmeegs statatsrecht (Beekman-bundel), Nijmegen 1987, p. 34 e.v., P.J. Langenberg, Ambtelijke aanspreekbaxheid, aanvulling op de lanende ministeriele verantwoordelijkhcid, Bestur 1988 , p. 61 e.v., M.A.P. Bovens, Verantwoordelijkheid en organisatie, Beschouwingen over aansprakelijkheid, institutioneel burgerschap en ambtelijke ongehoorzammeid, Zwolle 1990 , p. 161 e.v., M.E. Tuurenhout, Parlementaire controle en ambtelijke verantwoordelijkheid, Arnhem 1992, p. 194 e.v.

52. Hierower bestat zeer veel literatuur. Toonaangevend was M. Scheltema, Zelfstandige bestuursorganen, Deventer 1974. Recentelijk S.E. Zijlstra, Zelfstandige bestutursorganen in een democratische rechtsstaat, Den Haag 1997. Zie voor een overzicht van de belangrijlkste literatur: Kamerstukken II 2000-2001, 27426, nr. 3, p. 2.

53 S. de Smith, R. Brazier, Constitutional and administrative law, Penguin books 1998 , p. 208. Aan het hoofd van een dergelijke agency staat een "chief" executive" die uitsluitend verantwoording schuldig is aan de minister, mat onder omstandigheden 
Nederlandse zelfstandige besturursorganen maken deze deel uit van de 'civil services. De ministeriele verantwoordelijkheid is daarmee althans formeel in tact gebleven ${ }^{54}$ Tot dusverre lijken er geen aanwijzingen te bestaan dat deze situatie op problemen stuit. Op grond van recent bestuurskundig onderzoek naar verzelifstandigingsoperaties in het Verenigd Koninkrijk concludeert De Ridder zelfs dat een grote vrijheid van managen voor ambtelijke diensten goed kan samengaan met handhaving van de ministeriele verantwoordelijkheid. ${ }^{55}$

Op dit moment is er weinig reden om in het Nederlandse parlementaire stelsel een andere richting op te gaan. Zelfstandige verantwoording door ambtenaren stuit op grote bezwaren; zij tast het centrale aangrijpingspunt voor parlementaire controle in de kern aan. De macht van de ambtelijke dienst wordt minder grijpbaar omdat de toerekening daarvan niet langer integraal geschiedt maar gespreid. Met de ministers zou in wezen hetzelfde gebeuren als met de Koning in de negentiende eeuw. ${ }^{56}$ Zoals de macht van de Koning afnam toen de ministeriële verantwoordelijkheid werd ingevoerd, zo zal de positie van de ministers verzwakken indien ambtenaren zich zelfstandig zouden verantwoorden. Thans zouden het de ambtenaren zijn die zich 'omdraaien': zij zouden niet langer fungeren als dienaren van de minister, maar als dienaren van het parlement. Voor het parlement wordt het er echter niet beter op. Het krijgt via ambtenaren wellicht meer informatie, maar zijn macht neemt af. De ambtellijke dienst zal door de vele ambtelijke aanspreekpunten ongrijpbaar zijn geworden.

De situatie ligt niet wezenlijk anders bij de verzelfstandiging van ambtelijke diensten. Deze heeft de laatste decennia op substantielle schaal plaatsgevonden door de vorming van een betrekkelijk groot aantal zelfstandige bestuursorganen. De oorspronkelijke filosofie was gebaseerd op een paradox. Juist door de formele zeggenschap van de minister te beperken kan de relatie met de verzelfstandigde organisatie duidelijker worden vormgegeven, waardoor ook meer invloed op die organisatie kan worden uitgeoefend, zo was de gedachte. Aldus zou de ministerièle verantwoordelijkheid worden versterkt.

De praktijk heeft evenwel eerder het tegendeel te zien gegeven. De Algemene Rekenkamer heeft in zijn onderzoek van 1995 geconstateerd dat inrichting en vormgeving van de afzonderlijke zelfstandige bestuursorganen dermate verschillend zijn geregeld dat gesproken kan worden van een wildgroei. Voorts stelde de Rekenkamer vast dat de wijze waarop ministers invulling geven aan hun ministeriele verantwoordelijkheid woor zelfstandige bestuursorganen veel tekort-

well rechtstreks vragen van het parlenent mag beantwoorden. Natar verluid werkt ongeveer driekwart van de ambtenaren bij een executive agency.

$54 \mathbb{R}$. Brazier, Ministers of the Crown, Oxford 1997, p. 278, 279.

55 I. do Ridder, Verzelftandiging en het primaat wan de politiek. De Britse executive agency, Beleid \& Mastschappij 1998, p. 125 e.v., m.n. p. 140. In deze zin ook H.R.B.M. Kummeling, a.w. p. 39. Er wordt echter ook gesteld dat de instelling wan "executive agencies" in de praktijk heeft geleid tot verzwakking van de ministeriele verantwoordelikheid voot ambtelijke fouten. Zie 1. Loveland, Constitutional Law. A Critical Introduction, London, Edinburgh, Dublin 2000, p. 275.

56 Van der Pot-Donner, Handboek van het Nederlandse staatsrecht, Zwolle 1983, p. 332. 
komingen vertoonde. ${ }^{57}$ Ook meende de Rekenkamer dat ministers over onvoldoende bevoegdheden beschikten om hun verantwoordelijkheid te kunnen dragen. ${ }^{58}{ }^{59}$ Als reactie hierop is een tegenbeweging op gang gekomen om thet primaat van de politiek" te herstellen.

Naar mijn mening dient met de instelling van zelfstandige bestuursorganen grote terughoudendheid te worden betracht. Bestuurskundig onderzoek $\|_{j}$ kt erop te wijzen dat bij recent verzelfstandigde onderdelen van ministeries politieke verantwoording als centrale waarde aan belang heef ingeboet. ${ }^{60}$ Deze situatie schept aanzienlijke risico's voor de mimister op wiens beleidsterrein het desbetreffende zelfstandig bestuursorgaan actief is, omdat deze viteindelijk toch door het parlement op eventuele tekortkomingen zal worden angesproken. ${ }^{61}$

Met het voorgaande wil niet gezegd zijn dat het staatsrecht zich per definitie tegen een vergaande beperking van de ministerielle verantwoordelijkheid verzet. Maatschappelijke ontwikkelingen kumnen noodzaken tot - soms ingrijpende veranderingen van het staatsrechtelijke bestel. Wel moeten wij ons steeds blijven realiseren dat de ministeriële verantwoordelijkheid een elementair bestanddeel vormt van ons parlementaire stelsel. Wie de ministeriële verantwoordelijkheid ingrijpend wil aanpassen, stelt in wezen het parlementaire stelsel ter discussie. Tot dergelijke aanpassingen dient men pas te komen vanuit - ik citeer hier Burkens - 'het klare bewustzijn dat men overgaat op een andere staatsrechtelijke structuur? ${ }^{62}$ Als het er op aankomt blijkt de geneigdheid daartoe, buitengewoon gering. Een belangrijk symptoom van die behoudendheid is dat de maatschappelijke druk op het parlement om ministers over de meest uiteenlopende onderwerpen ter verantwoording te roepen, de laatste decennia alleen maar sterker lijkt te zijn geworden.

Maar - zo zou de vervolgvraag kunnen luiden - zijn er voor de parlementaire controle dan geen goede alternatieven voorhanden? Bovens heeft in zijn interessante oratie gepleit voor nadere bezinning omtrent andere vormen van publieke verantwoording. Naar zijn mening wordt met de thans bestaande hiërarchische verantwoordingsmechanismen, onvoldoende recht gedaan aan de horizontalise-

57 Kamerstukken II 1994-1995, 24130, nr. 3, p. 4.

58 Kamersulkken $111994-1995,24130$, nr. 3, p. 53

59 Het kabinetsstandpunt over het rapport van de Algamene Rekenkuther droeg als titel: "Herstel van het primat wan de politick bij de atasturing van zetfstandige bestuursorganen'. Zie Kamerstukken II 1994-1995, 24130, ar. 5. Op grond hiervan is een toetsingskader tot stand gekomen in de worm van de Aanwijzingen inzake zelfstandige bestutursorganen (Besluit wan de minister-president dd. 5 september 1996, Stcrt. 1996, 177) en heeft een doorlichting van de bestaande zelfstandige bestuwrsorganen plaatsgevonden (Kamerstukken II 1996-1997, 25268, nr. 1). Deze heeft geleid tot allerle initiatieven ter versterking van de ministerite verantwoordelijkheid, waaronder nieuwe wetgeving. Zoals hiervoor reeds vemeld is oun voorstel voor een Kaderwet zelfstandige bestunrsorganen onlangs bij de Tweede Kamer aanhangig gemaakt. Zie Kamerstukken 11 2000-2001, 27426, nrs. $1-3$.

60 MA.P. Bowens, aw., p. 9. Zie ook P. Plug, M. Bovens, Ambtelijke zellstandigheid en politieke verantwoordelijkheid, Openbaar bestur 1999, p. 7 e.v.

61 Vgl. S.E. Zijlstra, a.w., p. 129.

62 M.C. Burkens, a.w., p. 9. 
ring van het openbaas bestuur. ${ }^{6}$ Hij noemt een drietal alternatieven die deels reeds in de bestuurlijke praktijk zichtbaar zouden zijn, te weten ${ }^{64}$

- directe ambtelijke verantwoording aan het parlement;

- verantwoording aan andere publieke verantwoordingsfora dan de traditionele politicke organen; hij vermeldt in dat verband het reeds genoende WRRwoorstel tot instelling van een Kwaliteitskamer; ${ }^{63}$

- werantwoording aan particuliere actoren, zoals media, belangengroepen of zelfs indiwiduele burgers.

Cruciaal is daarbij zijn stelling dat daar waar de publieke machtsuitoefening pluriformer wordt, ook de verantwoordingsrelaties pluriformer dienen te worden. ${ }^{66}$ Uit het voorgaande is al wel gebleken dat ik mij niet in dit standpunt kan vinden. Naarmate de macht van de ambtelijke dienst gefragmenteerder wordt, is er juist behoefte aan centrale aangrijpingspunten met behulp waarvan het doen en laten van ambtelijke diensten gecontroleerd kan worden. ${ }^{67} \mathrm{Ik}$ verwijs naar de zojuist geschetste ontwikkelingen rond zelfstandige bestuursorganen waaruit een duidelijke tendens is af te leiden in de richting van herbevestiging van de ministerisle verantwoordelijkheid.

Daarnaast is er het punt van de democratische legitimatie. Het is misschien waar - zoals Bovens ook opmerk $t^{68}$ - dat de parlementaire verantwoording aan legitimiteit heeft ingeboet, maar vooralsnog mag worden betwijfeld of de door hem gesuggereerde alternatieven op dit punt beter scoren. In elk geval zijn zij nog veel te weinig uitgewerkt om te kunnen dienen als volwaardige alternatieven naast of in plaats van de parlementaire verantwoording via de ministeriêle verantwoordelijkheid. Op korte termijn lijkt daar ook geen concreet zicht op te bestaan.

Het ligt derhalve voor de hand om aan te nemen dat zolang ons geen helder alternatief voor ogen staat, we zuinig moeten omspringen met de bestaande staatsrechtelijke structuren. Dit betekent niet dat we ons binnen die structuren bewegend, rigide moeten opstellen. De huidige kaders bieden veel ruimte voor aanpassingen in werkwijze en ambtelijk gedrag. De laatste jaren worden op dit punt nuttige inspanningen verricht, met name als het gaat om het systematiseren

63 Het is overigens niet precies duidelijk in hoeverre Bovens vindt dat deze vormen van verantwoording de ministeriele verantwoordelijkheid als verantwoordingsmechanisme moeten gaan vervangen. Hij spreekt ( $\mathrm{p}$. 18) over 'verplaatsing van een deel van de publitoke veruntwoording".

64 M.A.P. Bovens, a.w., p. 4 e.v.

65 lk kom op dit voorstel nog tefig in par. 10. De instelling van een $K$ waliteitskamer beoogt - althans in de gedachtegang van zijn huidige woorzitter - de ministeriele verantwoordelijkheid niet af te schaffen of in formele zin te beperken. Zie M. Scheltema, NJB 2000, p. 2131 in reactie op A. W. Heringa.

66 M.A.P. Bovens, a.w., p. 18.

67 E. van Thijn e.a., De sorry-Cemocratic. Recente politieke affaires en de ministeriele verantwoondelijkheid, Amsterdam 2000, p. 244.

68 M.A.P. Bowens, a.w. p. 12. 
van de bestuurlijke verhoudingen tussen kerndepartement en witwoerende diensten en de wijze waarop in die verhoudingen invulling moet worden gegeven aan de toezichtsfunctie; ik verwijs bijvoorbeeld naar het in 1998 verschenen rapport 'De ministeriële verantwoordelijkheid ondersteund' van de commissie Holtslag. ${ }^{69}$

Hetgeen voorts binnen de huidige systematiek denkbaar is, is een zekere uitbreiding van het aantal politiek verantwoordelijk bewindslieden. Dit zou het voordeel kunnen hebben dat het onderdeel van de ambtelijke dienst dat door elke afzonderlijke minister of staatssecretaris moet worden bestuurd minder onnvangrijk is en dus beter beheersbaar. Uiteraard hoeven wij daarbij niet zo ver te gaan als in het Verenigd Koninkrijk. De regering-Blair telde in haar beginperiode 113 ministers. Daarvan is echter slechts een beperkt aantal nid van het kabinet: naast de Prime Minister betreft het zestien ministers die tevens hoofd zijn van een departement ('departmental ministers'). ${ }^{70}$ Vertaald naar de Nederlandse situatie zou het denkbaar zijn dat er in de toekomst naast een beperkt aantal ministers die gezamenlijk de ministerraad blijven vormen, meer staatssecretarissen worden aangesteld dan op dit moment het geval is. Daarbij dient te worden afgewogen in hoeverre het genoemde voordeel van een dergelijke constructic opweegt tegen het mogelijke nadeel van een toenemende coördinatieproblematiek.

\section{6. 'De minister is onschendbaar; de ambtenaren zijn verantwoordelijk'}

Uitgaande van onverkorte handhaving van de ministeriale verantwoordelijkheid zijn in de praktische invulling allerlei modaliteiten denkbaar. Zo rijzen allerlei vragen omtrent de wijze waarop de minister verantwoording moet afleggen. In de officiële doctrine betekent verantwoording afleggen meer dan inlichtingen geven: het impliceert tevens dat de minister het gevoerde beleid uitlegt, motiveert en verdedigt. ${ }^{71}$ Maar betekent dit nu ook dat een minister elke ambtelijke fout waar hij op het beslissende moment geen weet van had, naar buiten toe door dik en dun moet verdedigen? De minister staat voor hetgeen onder zijn verantwoordelijkheid heeft plaatsgevonden, maar hoever moet hij daarmee gaan?

In het Verenigd Koninkrijk wordt reeds lang over deze vraag nagedacht, ${ }^{72}$ maar zijn de grenzen nooit precies komen vast te staan. Voorop staat dat de minister

69 De ministeriele verantwoordelijkheid ondersteund. Een checklist voor een systematische beschrijving en analyse van toezichtsartangementen, Den Hatg 1998. Zie ook Vertrowwen in onathankelijkheid, Eindadvies Ambtellike Commissie Toezicht (commissie-Borghouts), Den Haag 2000, watrin woor de toezichtstunctie in bepalde gevallen wordt gepleit voor externe verzelfstandiging.

70 L. Prakke, Het Verenigd Koninkrijk van Groot Brittannie, in: L. Prakke, C.A.J.M. Kortmann, Het staatsrecht van de landen vath de Europese Unie, Deverter 1998, p. 791 e.., m.n. p. 814,815 .

71 Steekhoudend ministerschap, a.w., p. 8.

72 G. Marshall, Ministerial responsibility, Oxlord University Press 1989. Hierin zijn diverse relevante documenten gepubliceerd uit literatuur en parlementaire praktijk. 
zich bij ambtelijk falen niet aan zijn verantwoordelijkheid kan ontrekken. 'He must, in the last resort, carry the can ${ }^{73}$ In de praktische uitwerking echter worden vaak onderscheidingen aangebracht. Als de tekortkoming te wijten is aan een slechte organisatie of gebrekkig toezicht, dient de minister deze volledig voor eigen rekening te nemen. Maar indien er een ernstige fout is begaan door een ambtenaar waar de minister buiten zijn schuld geen enkele weet van heeft en thij de bewuste gedraging ten zeerste afkeurt, ligt het anders. In dat geval wordt meestal aangenomen dat de minister het recht heeft on in het openbaar te vertellen wat er op het departement verkeerd is gegaan en dat hij deze gang van zaken betreurt. ${ }^{74}$ Benadrukt wordt wel dat dit slechts bij hoge uitzondering aangewezen is. Indien individuele ambtenaren te vaak voorwerp worden van opentare kritiek, dan kan niet van ambtenaren verwacht blijwen worden dat zij deze onbeantwoord laten. ${ }^{2 / 5}$

Indien ik deze uitgangspunten vergelijk met de Nederlandse situatie, moet worden vastgesteld dat de grenzen bij ons tegenwoordig veel ruimer worden getrokken. Het openlijk bekritiseren van ambtenaren door ministers is geen uitzondering meer. Integendeel, er zijn terugkijkend op de laatste jaren vele voorbeelden te geven van bewindslieden die in soms stevige bewoordingen ambtenaren in het openbaar de les hebben gelezen. ${ }^{76}$ Een van de onschuldigste reacties hierop in ambtelijk. Den Haag is er een van cynisme. Een bekende grap luidt dat heimelijk en zonder tweederde meerderheid een belangrijke grondwetswijziging zou zijn doorgevoerd. Het moderne artikel 42 , tweede lid zou inmiddels luiden: de minister is onschendbaar; de ambtenaren zijn verantwoordellijk.

73 S. de Smith, R. Brazier, a.w., p. 194

74 G. Marshall, a.w, p. 10: "But what it comes down to it is that he can say out loud that he did not know, and say whose conduct it is that he is not bound to approve of when he disapproves of it'. Zie ook D.N. Chester, The Crichel Down Case, in: G. Marshall, a.w., p. 106 e.v. waarin de naar aanleiding van genoemde zaak gevoerde gedachtewisseling tussen regering en House of Commons over dit therna wordt beschreven. Voorts I. Loveland, a.w., p. 268 en 283.

75 D.N. Chester, a.w., p. 111, S. de Smitl, R. Brazier, a.w., p. 195.

76 Enkele voorbeelden: de uitatingen van de minister-president in de kwestic Dociers van Leeuwen in 1998 - waarin de procureursugeneraal van thet OM openlijk kinderachtig en onvolwassen gedrag werd verweten (Kok valt uit natar procureurs-generaal, NRC Handelsblad 24 januari 1998); de uillating van ex-minister van Justitie Sorgarager die - naar zij voorjaar 1998 publickelijk verklaarde - wel eens het gevoel had gehad dat haar ambtenaren een draadje spanden om haar ten val te brengen (Staf op Justitie 'wilde minister kapotmaken', NRC Handelsblad 29 april 1998)); de uitwal vatn de minister-president naar functionarissen van de luchtverkeersleiding na hun verhoor door de enquêtecommissie inzake de Bijlmerramp (Kabinet schorst verkeersleiders, NRC Handelsblad 6 februari 1999); de statssecretaris van LNV, die een te lakse houding werd verweten tegenover de import van dioxinekippen en zich hiertegen verweerde met de stelling dat zij te laat was ingelicht (Stert. II angustus 1999, nr. 152); de uitlating van minister van Economische Zaken Jorritsma die het voorstel van haar toenmalige secretaris-generaal Van Wijnbergen om het $O M$ te privatiseren alss 'onhandig' betitelde, hoewel zij naar verluidt het bewuste artikel van tevoren gelezen had (NRC Handelsblad 27 september 1999. 
Een dergelijke ministeriele opstelling is staatsrechtelijk onjuist. ${ }^{7}$ Indien de minister al enig licht mag laten schijnen tussen hem en zijn ambtenaren dan toch alleen in sporadische gevallen en in zeer terughoudende bewoordingen. Zeker van leden van een kabinet dat de ministeriezle verantwoordelijkheid will handhaven en veel nadruk legt op verbetering van het ambtelijk functioneren, mag worden verwacht dat zij ook zelf zich aan de spelregels houden. Ook in Neder* land moet uitgangspunt blijven hetgeen door Sir Thomas Dugdale in de in het Verenigd Koninkrijk bekende Crichel Down Case onder woorden is gebracht:

'I, as Minister, must accept full responsibility' to Parliament for any mistakes and inefficiency of officials in my Department, just as, when my offcials bring off any successes on my behalf, It take full credit for them",

Doch ook aan ambtelijke zijde bestaat voor de ministerißle verantwoordelijkheid soms onvoldoende oog. Het lekken van vertrouwelijke informatie lijkt een regelmatig voorkomend verschijnsel. ${ }^{79}$ Voorts hebben we de laatste jaren voorbeelden gezien van ambtenaren die hun minister niet tijdig en adequaat hebben geünformeerd of door andere handelingen, hun minister in ernstige politieke problemen hebben gebracht. Nieuwe vormen van departementaal bestuur zetten de situatie daarbij verder op scherp. Ambtenaren overleggen bij de voorbereiding van beleid of wetgeving meer met maatschappelijke groeperingen dan voorheen (interactieve beleidsvorming). ${ }^{80}$ Daarbij bestaat het risico dat ambtenaren zo* danig geünvolveerd raken in maatschappelijke netwerken, dat de minister in hun gezichtsveld naar de zijlijn verdwijnt. De ambtenaar beschouwt de minister dan al snel als een obstakel op weg naar de realisering van maatschappelijke afspraken. $^{81}$

77 In deze zin ook H.R. van Gunsteren, Politeke verantwoording; de waarde van incidenten, NJB 2000, p. 307 e.w. E.J. Janse de Jonge, Artikel 42, in: A.K. Koek* koek, de Grondwet. Een systematisch en artikelsgewijs commentaar, Deventer 2000 , p. $314 \mathrm{e.r.}$.

78 HC Deb. 530 Column 1186,20 juli 1954. Geciteerd in C. Turpin, British Government and the Constitution, London 1985, p. 353.

79 Voor een bestuurskundige analyse zij verwezen nat M.A.P. Bovens, H.G. Geveke, J. de Vries, Strikt vertrouwelijk lekken in het openbaar bestumir, Beleid \& Maatschappij 1993, p. 61 e.v. Overigens is niet gezegd dat allewn ambtenaren lekken; niet uitgesloten moet worden geacht dat ook bewindslieden zich hieraun schuldig kunnen maken.

80 A.J. Hoekema, I.C. van der Vlies (red.), Onderhandelend bestur, Amsterdan 1998. Het betreft hier een vijftal afzonderlijk verschenen deelstudies. In N. Huls, Onder. handelend wetgeven in de praktijk, Amsterdam 1998 (een van de wijf deelstudies) wordt ingegaan op de politick-ambtelijke aspecten (p. 202 e.w.). Zie voorts voor een rechtswergelijkende benadering $\mathrm{B}$. de Waard (red.), Negotiated Decision-Making, Den Haag 2000 . Een beschrijving van de problemen vanuit de ervaringen op het specifieke beleidsveld wan het ministerie wan VROM is te winden bij J.W. Duyvendak, M. Hoogbergen, Sturing van de leefomgeving: nuwe vormen van sturing, Open bestuur 1998, p. 10 e.v.

81 Vgl. M.A.P. Bovens, a.w., p. 10 die - met verwijzing natar literatuur - stelt dat in de meeste beschrijvingen van interactieve processen democratisch gekozen politici niel 
Het is op grond van het voorgaande niet overdreven te stellen dat er bij ambtenaren en ministers toenemende verwarring is ontstaan omtrent hoe zij zich ten opzichte vain elkaar moeten gedragen. Dit leidt soms tot een pleidooi voor het formuleren van spelregels voor politiek-ambtelijke verhoudingen. ${ }^{82}$ Alvorens de opportuniteit van dergelijke regels te bezien, keer ik terug naar het Verenigd Koninkrijk waar met de geschetste vormen van politiek-ambtelijke spelverruwing eveneens de nodige ervaring is opgedaan en men uiteindelijk is overgegaan tot de opstelling van een gedragscode.

\section{Gedragsregels in het Verenigd Koninkrijk}

In het Verenigd Koninkrijk heeft de zogenaande Westland-affaire veel invloed gehad op de ontwikkeling van de politiek-ambtelijke verhoudingen ${ }^{83}$ Westland was een Britse helikopterfabriek die in 1985 in financiële moeilijkheden was geraakt. Binnen de regering bestond verschil van mening over de manier waarop deze problemen moesten worden opgelost: de minister van Defensie (Heseltine) en - oorspronkelijk ook - de minister voor Handel en Industrie (Brittan) pleitten voor aansluiting van Westland bij een Europees samenwerkingsverband, de Prime Minister (Thatcher) was voorstander van samenwerking met een Amerikaans bedrijf. De ruzie binnen het kabinet liep zo hoog op dat het pleit uiteindelijk via de pers werd beslecht. De climax daarvan vond begin 1986 plaats. Heseltine zette in een brief aan de Lloyd Merchant Bank, die betrokken was bij de onderhandelingen over de Europese optie, uiteen waarom hij gekant was tegen samenwerking met de Amerikanen. Dit was tegen het zere been van mevrouw Thatcher: eerder was het verzoek van Heseltine om deze argumenten te vermelden in een brief van het kabinet aan Westland door Thatcher afgewezen.

Thatcher liet nu op haar beurt de Sollicitor-General een brief schrijven aan Heseltine waarin hij erop gewezen moest worden dat zijn brief aan Lloyd "enkele wezenlijke onnauwkeurigheden' bevatte. Enkele uren na aankomst van de brief op het ministerie van Heseltine, lekten delen van de brief uit naar de pers. De publieke commotie hierover was enorm. Twee weken later werd na een intensief onderzoek bekend dat een ambtenaar de brief had laten uitlekken en dat dit de goedkeuring had van de verantwoordelijke minister van Handel en Industrie

verschijuen als centrale actoren, maar als' 'stoorzenders, probleemgevallen of figuranten". Kritisch hierover ook E. van Thijn e.a., a.w., p. 244.

82 U. Rosenthal e.a., Openbaar bestuur, Alphen a/d Rijn 『996, p. 304 e.v., P. 't Hart, U. Rosenthal, Politick-ambielijke spelregels zijn nodig, NRC 5 november 1998 . Voor zoxer het gaat om spelregels tussen kerndepartementen en zelfstandige bestuursorganen zij voorts verwezen naar P. Plug, M. Bovens, Ambtelike zelfstandigheid en politicke verantwoordelijkheid, Openbaar bestuur 1999, p. 7 e.v.

83 P. Hennessy, The Westland Affair, in: G. Marshall (ed.), Ministerial responsibility, Oxford University Press 1989 , p. 80 e.v. In deze publicatie zijn ook passages gepubliceerd van het rapport dat de Defence Select Committee of the House of Commons terzake had uitgebracht (p. 134 e.v. Zie ook HC 519 (1985-6). Zie voor een Nederllandse beschrijving M.E. Tuurenhout, Parlementaire controle en ambtelijke verantwoordelijkheid, Arnhern 1992, p. 71 e.w. 
Brittan. Bovendien werd vastgesteld dat de perswoordvoerder van de Prime Minister met de gang van zaken had ingestemd. Thatcher verklaarde later in de House of Commons hierover niet door haar ambtenaren te zijn geinformeerd. Indien het haar gevraagd zou zijn - zo verklaarde zij - had zij niet met de gevolgde werkwijze ingestemd. ${ }^{84}$ De namen van de vijf ambtenaren die bij het lekken rechtstreeks betrokken waren geweest, waren intussen volop in de publiciteit gekomen. Deze hebben zich niet in het openbaar kunnen verdedigen. Het kabinet-Thatcher heeft het verzoek van de Defence Select Committee van de House of Commons om de betrokken ambtenaren te horen, hardnekkig geweigerd.

Hennessy heeft in een analyse van deze zaak helder beschreven hoe de betrokken ministers en ambtenaren diverse conventies betreffende de ministeriéle verantwoordelijkheid aan hun laars hebben gelapt. ${ }^{85}$ Het is dan ook niet verwonderlijk dat de Westland-affaire - die twee ministers de kop heeft gekost - in het Verenigd Koninkrijk heeft geleid tot een uitwoerig debat over de wijze waarop ministers en ambtenaren met elkaar behoren om te gaan. Vele officiäle verklaringen, rapporten en voorstellen van de zijde van regering en parlementaire commissies hebben vanaf 1985 elkaar opgevolgd ${ }^{86}$ Het debat heeft uiteindelijk geleid tot de vaststelling van de Civil Service Code: een gedragscode waarin een aantall rechten en plichten voor ambtenaren en ministers is vastgelegd. ${ }^{87}$ In de code wordt verwezen naar de Ministerial Code waarin voor ministers naast constitutionele verplichtingen ook een groot aantal gedragsregels en rechtspositionele voorschriften is opgenomen. De Ministerial Code bestond onder een andere benaming al veel langer, maar is pas in 1992 voor het eerst gepubliceerd en door Blair in 1997 nog gewijzigd. ${ }^{88}$

84 R. Brazier, a.w., p. 274.

85 P. Hennessy, a.w. p. 91

86 Een opsomming van deze voorstellen is te vinden bij R. Brazier, Ministers of the Crown, Oxford 1997, p. 133, 134.

87 Civil Service Code 1996,265 HC Deb. 10-12 (30 oktober 1985). Een belarigrifle stimulans tot de vaststelling van deze code werd gegeven door het eerste rappont wath de Nolan Committee on Standards in Public Luite (Cm 2850, 1995). De Civil Sorvice Code is gebaseerd op de Civil Service Order 1995 an is laatstelijk aangepast op it mei 1999 in verband met de wijziging van de positie van Schotland en Wales. Zij is te vinden onder www cabinet-office.gov.uk/central/1999/cscode.htm (latist bezocht op 17 januari 2001). Een kort commentarar op de diverse bepalingen geeft $\mathbb{R}$. Brazier, a.w., p. 136 c.v. Rechten en verplichtingen van ambtenaren worden woorts beschreven in het memorandum opgesteld door de Head of the Home Ciwil Service, "The duties and responsibilities of civil servants in relation to ministers" (Armstrong memorandum 1985, zoals gewijzigd op 17 juli 1996), te vinden onder www leeds. ac.uk/law/teaching/law6ew/min-1htm (laatst bezocht op 20 december 2000). Zie voorts de Civil Service Management Code, www.cabinet-office.gov.uk/civilservicel managementcode/csmc.pdg (laatst bezocht op 17 januari 2001 ).

88 Te vinden onder www cabinet-office.gow.uk/central/1997/mcode/p.01.htm (lawat bezocht op 17 januari 2001). De herziening in 1997 vond plaats naar aanleiding van het in de vorige noot genoemde rapport van de Nolan Committee. 
Wat is nu de inhoud van de Civil Service Code? In het eerste artikel wordt in algenene zin de constitutionele tak van de ambtelijke dienst onder woorden gebracht. Deze dient gericht te zijn op de integere, eerlijke, onpartijdige en objectieve ondersteuning van de zittende regering bij het formuleren van beleid, het uitvoeren van beslissingen en het beheren van overheidsdiensten. Deze algemene taak wordt vervolgens uitgewerkt in een aantal rechten en plichten van de Individuele ambtenaar. Zijn gedrag behoort in dienst te staan van verwerving en behoud wan het vertrouwen wan zijt minister. Dit is echter niet onwoorwaardelijk. Er moet rekening mee worden gehouden dat de ambtenaar ook met toekomstige ministers moet kunnen samenwerken. Dit vereist naast dienstbaarheid ook een zekere afstand tot de partijpolitiek. De minister is daarom verplicht on de politieke onpartijdigheid van de ambtelijke dienst te waarborgen en ambtenaren miet te verleiden tot handelingen die met de Civil Service Code in strijd zijn.

Omtrent de wijze van advisering aan de minister bevat de Code een aantal klassteke 'Weberiaanse" bepalingen. De ambtenaar is volgens de Code verplicht tot eerlijke en onpartijdige advisering aan de minister 'without fear or favour'. Indien nodig is hij dus uitdrukkelijk gehouden tot het geven van adviezen die de minister politiok wellicht niet goed van pas komen. De minister op zijn beurt is verplicht ambtelijke adviezen serieus in overweging te nemen bij het nemen van zijn beslissing. Indien de minister eenmaal een beslissing genomen heeft, dienen ambtenaren mee te werken aan een loyale uitvoering 'with precisely the same energy and good will, whether they agree with it or not'."

Voor de dagelijkse werkrelatie is een goede omgang met informatie van cruciale betekenis. De Code is daar dan ook relatief uitwoerig over. Er wordt uitdrukkelijk voorgeschreven dat de ambtenaar alle informatie die de minister nodig heeft, moet verschaffen. Ambtenaren brengen schade toe aan de ambtelijke integriteit indien zij opzettelijk relewante informatie achterhouden. Voorts mag niet zonder toestemming informatie in de openbaarheid worden gebracht. De Code kent een uitvoerige bepaling die elk misverstand omtrent de ongeoorloofdheid wan lekken uitsluit. Als sluitstuk van de Code is voor ambtenaren die menen dat van hen illegale of onethische handelingen worden gevergd, voorzien in een klokkenluidersregeling. Na de situatie intern te hebben aangekaart, is hij bevoegd de zaak te melden bij de onafhankelijke Civil Service Commissioners. Indien de zaak niet volgens deze procedure naar tevredenheid kan worden opgelost, dient de ambtenaar volgens de Code een keuze te maken: of hij aanvaardt hetgeen van hem verlangd wordt of hij neemt ontslag.

Het debat over politiek-ambtelijke verhoudingen wordt tot op de dag vandaag op intensieve wijze grevoerd. De Neill Committee on Standards in Public Life heeft in januari 2000 een rapport uitgebracht waarin wordt voorgesteld een Civil Service Act voor te bereiden die de Civil Service Code van een wettelijke grondslag moet voorzien. ${ }^{90}$ Voorts wordt de aanbeveling gedaan om voor het handelen

90 Sixth Report of the Committee on Standards in Pablic Life, Reinforcing Standards, Cm 4557 , p. 64 e.v. Op Interuet te vinden onder www official-documents.co.ukt document/cm45/4557/4557.htm (geradpleegd op 18 januari 2001). Het betreft een herziening wan het onder noot 87 genoemde eerste rapport uit 1995. Het antwoord 
van externe adviseurs een afzonderlijke gedragscode op te stellen. De regering heeft de aanbevelingen grotendeels overgenomen. ${ }^{91}$ Voorts bereidt de Public Administration Select Committee van de House of Commons een rapport voor over de toepassing van de Ministerial Code en de wijze waarop de ministeriêle verantwoordelijkheid onder deze code functioneert. ${ }^{92}$

\section{Spelregels in politiek-ambtelijke verhoudingen?}

Wat kunnen wij hiervan leren met het oog op de Nederlandse situatie? Het lijkt op het eerste gezicht misschien niet erg aantrekkelijk om de relatie tussen ministers en ambtenaren te belasten met het formuleren van enigszins voor de hand liggende omgangsregels. Het past ook niet in de huidige beleid van de regering die ten strijde is getrokken tegen te vergaande juridisering van bestuurlijke en maatschappelijke verhoudingen. Anderzijds moet worden vastgesteld dat hoe ambtenaren en ministers zich ten opzichte van elkaar behoren te gedragen in de huidige tijd veel minder vanzelfsprekend is dan wellicht vroeger het geval was. In artikell 50 ARAR staat weliswaar wermeld dat ambtenaren zich moeten gedragen zoals een goed ambtenaar betaamt, maar wat beschouwd moet worden als een 'goed ambtenaar" is voorwerp van aanhoudende discussie.

Wat derhalve lijkt te ontbreken is een redelijke mate van overeenstemming over een helder idee van goed ambtenaarschap. ${ }^{93}$ In de literatuur wordt dit probleem vaak onder woorden gebracht in de vorm van concepten die tegenover elkaar zouden staan. Willen wij blijven vasthouden aan de klassieke Weberiaanse ambtenaar zoals wij die ook in het zojuist geschetste Engelse voorbeeld kunnen aantreffen of moeten wij daarvan afscheid nemen en de ambtenaar gaan beschouwen als een professionele manager met eigen verantwoordelijkheden?

Naar mijn mening gaat het hier om een valse tegenstelling. Zolang wij voor de ministeriële verantwoordelijkheid in ons staatsbestel een centrale plaats blijven inruimen - hetgeen ik voorlopig als een vaststaand gegeven beschouw - zall de relatie tussen de minüster en zijn ambtenaren in de eerste plaats beheerst dienen te worden door wederzijds vertrouwer. Dit brengt met zich dat klassieke waarden als loyaliteit, objectiviteit en onpartijdigheid ook voor de moderne ambtenaar centrale uitgangspunten zullen blijven. De regering heeft dit recentelijk nog eens terecht onderstreept. ${ }^{9.4}$ Binnen dat kader is echter veel mogelijk. Dat

van de regering dd. 26 jult 2000 (Cm 4817) is te winden onder ww officialdocuments.co.uk/document/cm48/4817/4817-03.htm.

91 Sixth Report, a.w., p. 80 e.w.

92 Het rapport werd rond I febnari 2001 werwacht. Zie de verslagen wan de verhoren die de Public Administration Select Committee heelt gepubliceerd: HC 821 (1999. 2000), ook te vinden onder www parliament the-stationery-office.co.tk/pu/cm 199900/cmsel.../cmpubadm ht (laatst geradpleegd op 17 januari 2001). Prime Minister Blair heeft overigens geweigerd om voor de Comitte te verschinen.

93 In dezelfide zin de Raad van State in Jaarverslag 1997, p. 11.

94 Vertrouwen in verantwoordelijkheid, a. w., p. 15. Besturskundig onderzoek boves tigt dat dit ook daadwerkelijk het geval is. Zie $J$, de Ridder, Ministeriele ver- 
is in het verleden al wel gebleken. De in 1983 grondwettelijk erkende vrijheid van meningsuiting van ambtenaren wordt - behoudens door een enkeling - niet met de ministeriele verantwoordelijkheid in strijd geacht. Dit komt ook overeen met de praktijk. Weliswaar gaat het wel eens mis - zo was de kritiek van de voormalige secretaris-generaal van Economische Zaken Van Wijnbergen op het even daarvoor door het kabinet vastgestelde belastingplan minder gelukkig ${ }^{65}$ maar daamaast zijn er talloze gevallen die niet in de publiciteit komen waarin ambtenaren zonder dat dit op enig bezwaar stuit, hun professionele oordeel aan de buitenwereld kenbaar maken. Deze gang van zaken berust op de erkenning dat een ambtenaar feitelijk gesproken een eigen verantwoordelijkheid heeft met de daaraan inherente bewegingsruimte.

Deze ontwikkeling zou moeten worden voortgezet. Bewegingen in die richting zijn te vinden in de hiervoor genoemde regeringsnota "Vertrouwen in verantwoordelijkheid". Een voorbeeld is de op 1 januari 2001 inwerkinggetreden ambtelijke klokkenluidersregeling. ${ }^{96}$ Deze regeling beoogt ambtenaren die bij het Rijk misstanden aan de kaak willen stellen, onder bepaalde omstandigheden bescherming te bieden. Wat de uitgangspunten betreft is in de regeling een juist evenwicht bereikt tussen politieke en ambtelijke verantwoordelijkheden. Terecht is als uitgangspunt gekozen dat de ambtenaar de door hem veronderstelde misstand eerst intern behoort te melden en pas in laatste instantie aan de nieuwe Commissie integriteit rijksoverheid. Daar staat tegenover dat de regeling een te sterke rechtspositionele inslag kent. De secretaris-generaal fungeert in zijn hoedanigheid van hoogste ambtelijke gezag als eindstation voor interne meldingen. Er wordt uitsluitend aan hem overgelaten om de minister al dan niet van de melding in kennis te stellen. ${ }^{97}$ De rechtspositionele invalshoek verklaart ook dat de leden van de Commissie integriteit rijksoverheid het vertrouwen dienen te hebben van zowel werknemersorganisaties als wan werkgeverszijde. ${ }^{98}$ Naar mijn mening dient de klokkenluidersproblematiek echter nadrukkelijker in een staatsrechtelijk perspectief te worden geplaatst. De rol van de minister zou in de rege-

antwoordelikkheid en politiek-ambtelijke verhoudingen, in: D.J. Elzinga (red.), Ministeriele verantwoordelijkheid in Nederland, Zwolle 1994, p. 279 c. v.

95 Secretaris-generaal Van Wijnbergen vraggt zellf ontheffing uit zijn functie, Stert. 28 september 1999.

96 Beslut van de minister van Binnenlandse Zaken en Koninkrijksrelaties dd. 7 december 2000 , Stct, $2000, \mathrm{nr}, 243$. Het betref een tijdelijke regeling. Regelling in de Ambtenarenwet is voorzien voor medio 2002. Zie over de klokkenludersproblematick met name M.A.P. Bovens, Verantwoordelijkheid en organisatie, Zwolle 1990 , p. 261 c.v. E. Verhulp, Vrijheid van meningsuiting van werknemers en ambtenaren, Den Haag 1997, p. 245 e.v. Zie woor de ambtelijke klokkenluidersregeling in $\mathrm{EU}$-verband de voorstellen omtrent hervorming van de Commisste dd. 5 april 2000, COM (2000) 200 definitief, p. 55.

97 Artikel 2.1, weede en vijfde lid.

98 Artikel 32, derde lid. Weliswarar benoemt de minister van BZK de leden, doch de Sectorcommissie owerleg rijkspersoneel, bedoeld in art. $105 \mathrm{ARAR}$, is bevoegd voorstellen doen. Feitelijk betekent dit - zo vermeldt de toelichting op dit artikel dat een lid het vertrowwen dient te hebben wan de werknenersorganisaties, één lid het vertrouwen moet genieten van werkgeverszijde, terwijl de voorzitter het wertrouwen van beiden dient te bezitten. 
ling meer gewicht moeten krijgen. Uiteindelijk zou hij als degene die politiek verantwoordelijk is, over alle meldingen door de secretaris-generaal geünformeerd moeten worden. Daarnaast zou de minister van Binnenlandse Zaken en Koninkrijksrelaties de vrije hand moeten hebben om - desgewenst na overleg met werknemersorganisaties - de leden van de Commissie integriteit rijksoverheid te benoemen.

Afgezien van de inhoud mag betwijfeld worden of deze regeling in de praktijk veel betekenis zal hebben. Vanwege haar beperkte reikwijdte mag worden verwacht dat zij zelden of nooit zal worden toegepast. Er lijkt veel meer behoefte aan verdere gedachtevorming over hoe te handelen in situaties die in politiekambtelijke verhoudingen dagelijks of althans regelmatigg voorkomen. Ik doel dan op vragen als:

- Op welke wijze dienen ambtenaren te bepalen welke informatie aan de minister moet worden doorgegeven? Hoe dient informatie op politieke gevoeligheid te worden geselecteerd?

- Wanneer en op welke wijze dienen ambtenaren de minister te raadplegen over de inzet en de mogelijke vitkomst van onderhandelingen in nationale en internationale overlegsituaties?

- Op welke wijze dienen ambtenaren hun minister te adviseren? Doet hij dit objectief en onpartijdig met aanreiking van recel mogelijke alternatieven of mag zijn advisering eenzijdig en politiek gekleurd zijn?

- Op welke wijze gaat de minister om met ambtelijke adviezen? Is het in beginsel gewenst dat hij de betrokken ambtenaar uitleg geeft indien hij van zijn advies is afgeweken of voomemens is zulks te doen?

- In hoeverre is de minister gehouden indien hem bepaalde keuzes worden voorgelegd, de ambtenaar met duidelijke instructies op pad te sturen? Op welke wijze wordt toegezien op de naleving van eventuele instructies?

- Moet de minister het verrichten van het politieke handwerk - zoals het onderhandelen met Kamerleden over concept-amendementen of moties - steeds zelf verrichten of mag hij dergelijke activiteiten onder omstandigheden aan zijn ambtenaren overlaten?

- Dient de minister ambtelijke fouten in de openbaarheid steeds voluit verdedigen of mag hij daartoe een zekere distantie bewaren? En indien het laatste het geval is, tot hoever mag de minister daarmee gaan?

- Onder welke omstandigheden en op welke wijze behoort de minister signalen die wijzen op tekortkomingen of misstanden binnen het departement, te laten onderzoeken? Welke regels moeten daarbij gelden om de zorgvuldigheid van het onderzoek te waarborgen, mede met het oog op de rechtspositionele consequenties die uit een dergelijk onderzoek zouden kunnen voortvloeien? ${ }^{99}$

99 Vgl. E.J. Daalder, Algemene regels van behoorlijk onderzoek, NTB 2000, nr. 8, p. 251,252 . 
Deze en andere yoor de praktijk uiterst relevante attitudevragen behoeven nadere aandacht en overdenking. $\mathrm{kk}$ zou daabij niet bij voorbaat willen uitsluiten dat de resultaten daarvan hun weerslag krijgen in enkele globale gedragsregels ${ }^{100}$ naar Brits model. De Britse code laak zien dat daarbij niet alleen gekeken moet worden naar de ambtelijke kant, maar ook naar gedragsnormen woor ministers. Voorts zou helder moeten zijn dat eventuele richtlijnen niet gaan fungeren als juridisch keurslijf. Zij zouden moeten dienen als handreiking die ambtenaren en ministers in de praktijk van alledag enig houvast kan bieden. Voorbeelden van thoe het zou kinnen, zijn reeds te vinden in de huidige Aanwijzingen inzake externe contacten van rijksambtenaren. Hierin zijn - de hiervoor reeds genoemde - afwegingsfactoren vastgelegd die als leidraad dienen bij het bepalen van de grenzen van de vrijheid van meningsuiting van ambtenaren (art. 125a Aw). ${ }^{101}$ Denkbaar zou zijn dat de reikwijdte van de aanwijzingen wordt uitgebreid en hieraan volgens hetzelfde stramien enkele spelregels voor politiek-ambtelijke verhoudingen worden toegevoegd.

\section{Contacten tussen Tweede Kamer en ambtenaren}

De problematiek van spelregels doet zich niet alleen voor in de verhouding tussen ambtenaren en ministers, maar ook tussen ambtenaren en de Tweede Kamer. Zoals hiervoor bleek zijn dergelijke contacten mogelijk met instemming van de verantwoordelijke minister. Voorgeschreven is dat de contacten in alle gevallen beperkt blijven tot het geven van inlichtingen van feitelijke aard.

Deze regeling is buitengewoon summier vergeleken met hetgeen in het Verenigd Koninkrijk kan worden aangetroffen. In 1980 zijn uitwoerige richtlijnen tot stand gebracht betreffende de wijze waarop contacten tussen ambtenaren en Select Committees van de House of Commons moeten verlopen, meestal aangeduid als de 'Osmotherly rules'. ${ }^{102}$ De ministeriële verantwoordelijkheid staat daarbij weliswaar centraal, maar binnen dat kader toont de regeling interessante nuances.

100 Gedragscodes zijn ook bif andere beroepsgroepen een normaal verschinsel. Voor ambtenaren zijn bopalde gedragsregels omtrent ambtelijke integriteit reeds in de Ambtenarenwet of de darop gebaseerde regelgeving opgenomen, maar deze hebben doorgans niet direct betrekking op de verhouding met de minister. Zie voorts de Justitiecode, uitgebracht door het ministeric wan Justitie in januari 2001.

101 Besluit van de minister-president d.d. 19 mei 1998, Stcrt. 1998, nr. 104 (Aanwijzing 15). Zie hiervoor par. 2.

102 Departmental evidence and responses to Select Committees (Osmotherly rules), Office of Public Service 1980, zonls geamendeerd in 1997, te vincten op www leeds. ac.uk/aw/teaching/law6cw/min-1.htm (latst geraadpleegd op 20 december 2000). Passages uit deze regels zijn gepubliceerd in M. Allen, B. Thompson, Cases \& Materials on Constitutional \& Administrative Law 2000, p. 338 e.w. Zie voorts me! dezelfide strekking de Memorandum of Guidance for Officials appearing before Select Committees (1980), welke te vinden zijn in de bijlage bij HC 100 (1986-87), Cm 78 (1987). 
Krachtens de Osmotherly rules staat voorop dat ambtenaren die verschijnen voor Select Committees dit doen namens hun minister en daarbij gebonden zijn aan zijn instructies. Dat is geheel in lijn met de individuele ministeriële verantwoordelijkheid die - zoals eerder opgemerkt - ook in het Verenigd Koninkrijk voorop staat. Omtrent wie voor een Select Committee moet verschijnen is de situatie genuanceerder. ${ }^{103}$ Het uitgangspunt luidt dat de minister bepaalt welke ambtenaar hem vertegenwoordigt. Indien een Select Committee echter aangeeft een specifieke ambtenaar te willen horen, zal een minister deze wens in beginsel honoreren, behoudens een tweetal situaties:

- In de eerste plaats belroudt de minister het recht om de naan van een andere ambtenaar te suggereren dan door de Select Committee genoend indien de minister vindt dat die ander geschikter is om over het betreffende onderwerp te worden gehoord. Ook kan hij aangeven zelf te willen verschijnen indien tussen minister en Select Committee geen overeenstemming wordt bereikt;

- In de tweede plaats geldt dat een Select Committee niet mag fungeren als rechter die disciplinaire straffen oplegt. Indien de verwachting bestaat dat de betreffende ambtenaar ondervraagd gaat worden over zijn persoonlijke verantwoordelijkheid voor een bepaalde gebeurtenis en hetgeen hem terzake zou kunnen worden verweten, kan de minister zelf voor de Select Committee verschijnen of een hoge ambtenaar aanwijzen om zulks namens hem te doen.

Indien evenwel de Select Committee tegen de zin van de minister persisteert in zijn verzoek om de ambtenaar te horen, blijft deze formeel gesproken verplicht om te verschijnen. Degene die weigert kan wegens 'contempt of parliament' worden gestraft. Verschijnt de betrokken ambtenaar wel, dan blijft hij ook dan onderworpen aan ministeriële instructies.

Deze regeling verdient in Nederland geen navolging. De praktijk in het Verenigd Koninkrijk lijkt indicaties te bevatten dat het niet goed werkt. In de incidentele gevallen waarin tussen Select Committee en minister geen compromis wordt bereikt over wie voor de Committee moet verschijnen, heeft de Select Committee zich steeds neergelegd bij het standpunt van de minister. In de eerder genoende Westland-affaire is de discurssie hoog opgelopen toen de Defence Select Committee bij het kabinet-Thatcher sterk aandrong om vijf ambtenaren te horen die bij het lekken van het rapport van de Sollicitor-General betrokken zouden zijn geweest. Toen het kabinet dit bleef weigeren, heeft de Defence Committee uiteindelijk niet cloorgezet omdat zij zag aankomen dat de desbetreffende ambtenaren dan vermoedelijk de ministeriêle instructie zouden krijgen om vragen niet inhoudelijk te beantwoorden. Dit zou de betrokkenen - in de woorden van de Defence Committee - in een uiterst pijnlijke en unfaire positie hebben ge bracht. ${ }^{104}$ Bovendien was de verschijning van betrokkenen voor de Committee

103 Zie Rule $40-42$.

104 Report from the Defence Committee of the House of Commons, $41 C 519(1985 * 6)$. nrs. 230-231. De relevante passiges zijn afgedrukt G. Marshall (ed.), a, w., p. 137. 
dan niet erg zinvol geweest. De informatie waarnaar de Committee op zoek was had zij van zwijgende ambtenaren niet gekregen.

Het latste doet de wraag rijzen of een eventuele verschijningsplicht zou moeten worden uitgebreid met een inlichtingenplicht zoals deze ook voor ministers geldt. Naar mijn mening is dit ongewenst. Indien een ambtenaar gedwongen kan worden om tegen de zin van zijn minister inlichtingen aan het parlement te verstrekken, ${ }^{105}$ bestaat het risico dat minister en ambtenaar tegen elkaar worden uitgespeeld. De voor de ministeriele verantwoordelijkheid essentiele vertrouwensrelatie tussen minister en ambtenaar komt dan in het geding. Daarom is het ook een illusie om te denken dat een ambtelijke inlichtingenplicht de positie van het parlement zou versterken. De positie van de minister wordt erdoor verzwakt met als gevolg dat de parlementaire controle alleen maar verder wordt bemoeilijkt. Voor de contacten tussen ambtenaar en parlement moet daarom uitgangspunt blijven hetgeen de politiek verantwoordelijke minister voor zijn rekening wenst te nemen.

Gegeven dat uitgangspunt kan gekozen worden voor een ruimhartige benadering. Om te laten zien hoe dat kan, keer ik terug naar de Britse Osmotherly rules. Hierin zijn ook richtlijnen te vinden voor de wijze waarop ambtenaren zich moeten opstellen als zij door een Select Committee worden gehoord. ${ }^{106}$ Als algemeen principe geldt dat zij verplicht zijn om daar waar mogelijk Select Committees behulpzaam te zijn. Daarbij blijft hun rol - anders dan in Nederland - nadrukkelijk ntet beperkt tot het gevern van feitelijke inlichtingen. Zij kunnen ook uitleg geven omtrent de inhoud van het gevoerce beleid en toelichten waardoor het beleid zoals het is vastgesteld, wordt gerechtvaardigd. Ambtenaren mogen wanuit hun professionele deskundigheid ook commentaar geven bij het beleid, mits dit in overeenstemming is met het beginsel van de politieke onpartijdigheid van de ambtelijke dienst. Zij dienen zich echter niet te laten verleiden tot discussies over de inhoud van mogelijke alternatieven. Dit is met name een probleem als er thema's aan de orde zijn die als politiek controversieel worden beschouwd. Indien de ambtenaar meent door leden van de Select Committee onder druk te worden gezet deze grens te overschrijden, geeft hij te kennen dat zij verdere vragen niet aan heri, maar aan de minister dienen te stellen.

Indien deze regels worden vergelijken met de Nederlandse Aanwijzingen, doet zich een merkwaardige paradox voor. Daar waar voor Britse ambtenaren enerzijds veel verdergaande beperkingen van de vrijheid van meningsuiting gelden dan in Nederland - ik verwijs naar het hiervoor genoemde Ahmed-arrest waarin deze beperkingen door het Europees Hof voor de Rechten wan de Mens werden geaccepteerd $^{107}$ - zijn er anderzijds ruimere mogelijkheden voor contacten met liet parlement. Het Britse voorbeeld laat naar mijn oordeel zien dat onze Aanwijzingen op dit punt onnodige beperkingen opleggen. Waar het om gaat is wat

$105 \mathrm{lk}$ laat de bijzondere regels ingevolge de Wet op de partementaire enquete buiten beschouwing.

1.06 Zie Rule $46-50$

107 EHRM 2 september 1998, NJCM-Bull. 1999, p. 946 e.w. m.n. R. Niessen. Zie voor de beperkingen die gelden voor ambtenaren op rijksniveau par. 4.4, van de Civil Service Management Code (noot 87). 
de minister voor zijn verantwoording wil nemen. Indien dat meer is dan alleen het geven van informatie van feitelijke aard, dan dient daar ook ruimte voor te zijn. Het ligt om praktische redenen ook voor de hand: het onderscheid tussen de verstrekking van feitelijke infornatie en de uitleg en verdediging van het beleid valt vaak moeilijk te maken. Denkbaar is zelfs dat de ambtenaar van de minister soms de ruimte krijgt om tijdens een overleg met de Tweede Kamer zijn eigen professionele oordeel te geven. Met name in kwesties die niet politiek controversieel zijn en in de besluitvorming nog niet zijn uitgekristalliseerd hoeft dit niet op bezwaren te stuiten, mits de minister en de ambtenaar vooraf overleggen over wat de ambtenaar te doen staat. Van de minister mag worden verwacht dat hij de ambtenaar bij die gelegenheid toereikende instructies meegeeft omtrent hoe ver hij mag gaan.

Vooralsnog zijn wij in Nederland echter blijven vasthouden aan een zeer restrictief beleid. Deze krampachtige houding wordt mede ingegeven door de opstelling van de Tweede Kamer. De VVD-fractie in de Tweede Kamer toonde zich onlangs geen voorstander van uitbreiding van contacten met ambtenaren. De VVD-woordvoerder Te Velthuis zag de bui al hangen:

'Als je dat gaat doen, zet je de deur open om de minister en zijn ambtenaren uit elkaar te jagen (...) Ik geef u op een briefje dat een aantal Kamerleden zich in dat geval zou specialiseren om de gaten tussen de minister en de ambtenaar te zoeken en hier vervolgens, zeker als je in de oppositie zit, fantastische taferelen van te maken. Maar ik weet niet of het openbaar bestuur daarmee zo gediend zou zijn. Wij voelen er in ieder geval niets voor; $(\ldots), 108$

Daarmee ben ik gekomen bij het laatste onderdeel van mijn rede: de controle door de Tweede Kamer.

\section{De controle door de Tweede Kamer ${ }^{109}$}

Zoveel belangstelling er in de wetenschap bestaat voor het reilen en zeilen van het openbaar bestuur, zo relatief weinig aandacht lijkt er soms uit te gaan naar het functioneren van het orgaan dat bij uitstek het openbaar bestuur behoort te controleren, de Tweede Kamer. ${ }^{110}$ Zonder de roll van de Tweede Kamer te belichten is de analyse niet compleet. Dit leidt soms to een eenzijdig perspectief,

108 Kamerstukken II 2000-2001, 26806, nr. 6, p. 40. Te Veithuis deed zijn uitlating tijdens een commissieowerleg dd. 8 november 2000 over de nota Vertrouwen in verantwoordelijkheid. Zie over deze nota par. 4.

109 Het begrip "controle" heeft verschillende betekenissen. Hierover onder meer J.A. wan Schagen, De Tweede Kamer der Staten-Generaal. Een stadsrechtelijke studie over hat organisatie en werkwijze, Zwolle 1994, p. 65 e.v. Ik vat het begrip hier rum op: het kan zowel de controlle op de uitvoering als de controle op de effecten van het regeringsbeleid omvatten.

110 De rol wan de Eerste Kamer is hier bescheiden en laat ik verder buiten beschouwing. Zie F. de Vries, De staatsrechtelijke positie van de Eerste Kamer, Deventer 2000 , p. 330. 
Deze vit zich onder meer door een onevenredige aandacht voor de ministeriële verantwoordelijkheid.

Een woorbeeld daarvan kan worden aangetroffen in het rapport 'Het borgen van publiek belang" van de WRR, dat vorig jaar verscheen. ${ }^{\text {II }}$ Hierin wordt het standpunt ingenomen dat als het gaat om de verantwoording over het goed functioneren van de overheidsorganisatie de ministeriële verantwoordelijkheid niet neer voldoet. Van een onpartijdige en systematische controle via de ministeriele verantwoordelijkheid is inmers geen sprake. ${ }^{12}$ On die reden wil de WRR een Kwaliteitskamer instellen die belast zou worden met een onafhankelijke toetsing van de ambtelijke dienst op basis van vooraf opgestelde kwaliteitsnormen. Een van de voordelen zou zijjn dat de ministeriële verantwoordelijkheid wordt ontlast: indien de minister door het parlement wordt aangesproken op incidenten staat hij niet met lege handen, maar kan hij verwijzen naar het 'overall' oordeel van de Kwal iteitskamer.

Hoezeer ik bepaalde onderdelen van de analyse ook juist acht, het rapport van de WRR vertoont mijns inziens een eenzijdige blikrichting. In wezen richt de WRR zich niet tegen de ministeriele verantwoordelijkheid op zichzelf, maar tegen de Tweede Kamer die de ministeriêle verantwoordelijkheid activeert. Omdat de Tweede Kamer de ambtelijke dienst via de minister partijdig en kwalitatief zwak controleert, zou er een nieuw orgaan moeten komen die deze tekortkomingen opheft. De mogelijkheid om te investeren in de kwaliteit van de parlementaire controle blijft buiten beschouwing. ${ }^{113}$ Toch ligt die mogelijkheid in het bestaande parlementaire stelsel meer voor de hand dan het in het leven roepen van een nieuwe instelling die het verantwoordingsproces ongetwijfeld verder zal compliceren. Een complicatie zal bijvoorbeeld zijn dat als de Kwalileitskamer werkelijk iets zou gaan voorstellen, de benoeming van de leden ongetwijfeld op ruime politieke belangstelling zal mogen rekenen. De door de WRR voorgestane onafhankelijkheid komt dan in gevaar. ${ }^{114}$

111 WRR, Het borgen wan publiek belang, Den Haag 2000. Zie verder n oot 45 .

112 De WRR voert dourmast ook an dat de partijdige controle via de ministeriele verantwoordelijklheid in sirjo is met de vereiste scheiding van machten: kwaliteitscontrole zou op exen onafhankelijke basis moeten geschjeden. Mijns inziens is dit teredu bestreden door A. W. Heringa. Zie NJB 2000, p. 2130.

113 Minister De Vries (BZK) heet het voorstel wan de WRR tijdens een mondeling overleg met de Tweede Kamer ower de Nota Vertrouwen in verantwoordelijkeid dd. 8 november 2000 afgeweren. Zie Kamerstukken II 2000-2001, 26806, ar. 6, p. 35 36. Zic voorts de opmorking van de minister eerder tijdens het overleg: 'Waarom zon de Tweede Kanter niet die kwalliteitskamer kumen zijn?" (p. 5).

114 Afwijung wan het voorstel wan de Kwalteitskaner neemt niet weg dat binnen de ambtelijke dienst de aandacht voor kwaliteitsverbetering verder kan worden geintensweerd. In de praktijk gebeurt er ook al veel. Zie daatover M. Scheltema, Voldoet de ministeriele verantwoordelikheid nog bij cen professionele overheidsorga nisatie?, NJB 2000, p. 1866. Een door hem genoemd woorbeeld is de wisitatie wan de departementale wetgevingsafdelingen door de onafhankelijke commissie-Grosheide. Het kabinetsstandpunt terzake is inmiddels an de Tweede Kamer gezonden. Zie Kamerstukken II 2000-2001, 27475, nr. 2, p. 29 e.v. 
De WRR heeft echter wel de vinger op de zere plek gelegd. Wat het partement betreft zijn er in wezen twee ernstige problemen. ${ }^{115}$ Het eerste probleem is de willekeur die de parlementaire controle lijkt te beheersen. Wat de parlementaire aandacht krijgt is in niet onbelangrijke mate van toeval afhankelijk. Het kont vaak voor dat als gevolg van incidenten onderdelen van de ambtelijke dienst plotseling in het centrum van de politieke belangstelling komen te staan. Daar zit niet alleen iets onbillijks in, de vraag is ook of andere problemen in de overheidsorganisatie die veel emstiger en struchureler van aard zijn, niet stelselmatig onderbelicht blijven. Het tweede probleem is de afrekencultuur die gaandeweg ons politieke systeem is binnengeslopen. Ik doel op het thatns veel voorkomende verschijnsel om indien er dingen fout gaan, met de wijsheid achteraf op zoek te gaan naar de schuldige. Belangstelling voor wat we met het oog op de toekomst van gemaakte fouten kunnen leren, verdwijnt niet zelden naar de achtergrond.

Bij de oplossing van het eerste probleem gaat het on de vraag hoe de Tweede Kamer er in zou kunnen slagen meer richting te geven aan zijn controlewerkzaamheden. ${ }^{116} \mathrm{Ik}$ wil voorop stellen dat er reeds ontwikkelingen door de Kamer in gang zijn gezet. ${ }^{17}$ Deze liggen vooral in de sfeer van de financiẻle verantwoording. Ik doel met name op de omvangrijke en ingewikkelde operatie "Van beleidsbegroting tot beleidsverantwoording' (VBTB), die als onderdeel van de begrotingscyclus moet leiden tot een jaarlijkse verantwoording door ministers op de derde woensdag in mei. In de kern gaat het er om dat de Kamer door middel van departementale jaarverslagen in de toekomst beter zou kunnen nagaan of de ministers de in het kader van de begroting geformuleerde doelstellingen ook daadwerkelijk hebben gehaald. ${ }^{118}$ Het betreft een hoopvolle aanzet die echter zijn

115 Zie ook M. Scheltema, a.w., p. 1863 en 1866.

116 Van Schagen stelt als rode drand vast dat de Kamer 'te weinig systematische aandacht heeft woor de vervulling van haar taken' (J.A. wan Schagen, a.w., p. 295). Hüj pleit onder meer voor de ontwikkeling van een structureel controlebeleid (p. 298).

117 Ook in het verleden heeft de Tweede Kamer reeds aandacht besteed aan mogelijke aanpassingen in de uitoefening wan de controletask. Zle het rapport onderzoek van de organisatie en de werkwijze Tweede Kamer (Kamerstukken II 1985-1986, 19336, nrs. 1-2; commissie-Dolman) en het rapport van de bijondere contuissie Vratapunten (Kamerstukken II 1990 1991, 21427, nr, 3; commissie-Deetman). Wazenlijke veranderingen zijn hieruit net voortgevloeid.

118 De basis woor de VBTB is gelegd door anvaarding wan de motie Melkert e.d. (Kamerstukken II 1998-1999, 26200, $\mathrm{nr}$. 6). De uitwerking is darop gegeven door de werkgroep Van Zjl (Kamerstukken II 1998-1999, 26347, nis. 1-2) walin sen lijst van onderwerpen was opgenomen waarover de Tweede Kamer prestatic gegevens opgenomen wilde zien in de departementale jaarverslagen van 1999. Zie hierover ook lhet rapport van de Algemene Rekenkamer (Kamerstukken II 1998 1999,26588, nr. 2). De regering heef vervolgens de notu "Van beleidsbegroting tot beleidsverantwoording' (Kamerstukken II 1998-1999, 26573, nr. I) uitgebracht ontrent hoe de operatic moet worden uitgevoerd. De eerste 'derde woensdag in me". wond plaats in de Tweede Kamer op 17 mei 2000 . Het eerste jatrverslag-nieuwe-stijl stat gepland voor mei 2003 . Zie over de hoofdlinen van de operatie G.H.O. wan Manen, Rumte voor doelmatigheid, Openbare uitgaven 2000, p. 54 e.v. alsook 
warde nog zal moeten bewijzen. Voorts wordt er binnen de Tweede Kamer gesproken over de insteling van een zogenaand verificaliebureau dat de Kamer zou moeten ondersteunen bij het formuleren en uibesteden van onderzoeksvragen. Ten slotte kan worden gewezen op de reeds langer bestaande ${ }^{119}$ procedure Controle Grote Projecten. Deze procedure beoogt de Kamer zich zodanig door de regering te laten voorlichten dat zij over bepalde grote projecten - zoals bijwoorbeeld de reorganisatie van het Openbaar Ministerie enkele jaren geleden in stat is on een afgewogen oordeel te vormen. ${ }^{120}$

Of deze deels nieuwe voorzieningen voldoende resultaten zullen opleveren zal de toekomst moeten untwijzen. Succes is niet verzekerd. Het risico is aanwezig dat het abstracte operaties blijven waarbij veel papier heen en weer wordt geschoven. Om ervoor te zorgen dat de Kamer echt kan controleren lijkt meer nodig: ik denk met name aan procedures warbij de Kamer niet uitsluitend af hankeljk is wan rappottages van de regering, maar daarnaast ook zelf op onderzoek uitgat en zich in dat kader laat voorlichten door deskundigen van zowel binnen als buiten de overheid.

Om elders inspiratie op te doen, keer ik opnieuw terug naar het Verenigd Koninkrijk. Om de controle op de regering te versterken is in 1979 een nieuw stelsel wan Select Committees in het leven geroepen. ${ }^{121}$ Select Committees zijn commissies van de House Commons ${ }^{122}$ warvan de meeste zijn belast met het kritisch volgen van de werkzaamheden van de departementen. Aanvankelijk werden Select Committees ad hoc voor bepaalde onderwerpen ingesteld, in de nieuwe situatie is er een permanente commissie per departement (in totaal 15). Daarnatst bestaat er nog een beperkt aantal Select Committees die zich richten op bijzondere thema"s, zoals Europese aangelegenheden en het functioneren van het openbaar bestuur (Public Administration Committee). ${ }^{123}$ De commissies bestaan uit 11 tot 17 leden. Zij worden hoofdzakelijk bezet door 'backbenchers'. Partijpolitieke scheidslijnen spelen mede hierdoor een minder belangrijke rol dan bij de Standing Committees, de wetgevingscommissies van de House of Commons. ${ }^{124}$ Belangrijk is ook de Liaison Committee. Deze bestaat uit de voorzitters van de afzonderlijke Select Committees. Zij ziet toe op het functioneren van het

R.P. van Puten, Het Jatrverslag van ministeries: een bron voor politick debat?, Openibare utugaven 2000, p. 59 e.v.

119 Kamerstukken II 198\% 1988, 18963, nr. 8 (tweede herdruk).

120 Art. 3 RvOTK. Hierover G.H. Hagelstein, De partementaire commissies, Groningen 1991, p. 296 e.u., J.A. van Schagen, a.w., p. $278,279$.

121 S. de Smith, K. Brazier, a.w., p. 292 e.v.

122 Ook de House of Lords heeft een aantal Select Committees die een goede reputatie genieten, onder meer als het gat om het Europese recht. Ik lat deze hier buiten beschouwing. Zie verder E. May, Parliamentary practice, London 1997, p.612 ev.

123 First Report trom the Liaison Committee, Shifting the Balance: Select Committees and the Executive, dd 3 maart 2000,300 HC (1999-2000). Ook te radplegen via www.publications.parliament. .00/cmselect/cmliaisn/300/30003.htm (geraadpleegd op 6 december 2000). Zie voorts M. Allen \& B. Thompson, a.w, p. 348 e.v.

124. L. Prakke, Het Verenigd Koninkrijk van Groot Brittannie, in: L. Prakke, C.A.J.M. Kortmann, Het stagterecht van de landen van de Europese Unie, Deventer 1998, p. 831. 
stelsel als geheel en cobrdineert de werkzaamheden. Dit laatste onder meer om overlapping van werkzaamheden te voorkomen.

De Select Committes selecteren zelf de onderwerpen die zij willen onderzoeken, na overleg met de Liaison Committee. Om luun onderzoekstaak te vervullen hebben zij formele bevoegdheden. $\mathrm{Zij}$ horen met name ministers en ambtenaren, maar kunnen ook externe deskundigen uitnodigen. Zij zijn allen verplicht om te verschijnen; in de praktijk vindt er echter vaak overleg plaats, met name over welke ambtenaren door de Committee zullen worden ondervraagd. Voorts mogen zij documenten opvragen bij de departementen. Zij worden bij hun werkzaamheden ondersteund door een of meer griffiers, administratief personeel en ad hoc aan te stellen adviseurs en deskundigen. ${ }^{125}$ Indien de Committees hun onderzoek hebben afgerond, leggen zij hun bevindingen vast in een rapport aan de "House as a whole', eventueel gepaard gaand met aanbevelingen.

Tot dusverre worden de resultaten van deze nieuwe werkwijze als positief ervaren. ${ }^{126}$ De leden van de Select Committees blijken een gedegen kennis en ervaring omtrent de werkzaamheden van het betreffende departement te hebben opgebouwd. De rapporten zijn diepgaand. $\mathrm{Zij}$ worden veelall unaniem uitgebracht. De regering wordt regelmatig over partijgrenzen heen kritisch bejegend. Daarnaast zijn er echter ook knelpunten. ${ }^{127} \mathrm{Er}$ is kritiek op de benoeming van de leden van de Committees die volgens de critici op een onafhankelijkere basis zou moeten geschieden. Voorts wordt geklaagd over de lage aanwezigheidsgraad van sommige leden. ${ }^{128}$ Het afgelopen jaar is naar aanleiding van kritische rapportages van de Liaison Committee in de House of Commons hierover uitvoerig van gedachten gewisseld, onder meer in een plenair debat tussen de Prime Minister en de Leader of the Opposition. ${ }^{120}$ Opvallend aan dat debat was dat Blair daarin vooral de draak stak met de leider van de Conservatieven, maar de inhoudelijke

$125 \mathrm{HC}$ Factsheets - $\mathrm{P} 2$, te vinden onder www parliament.uk/commons/lib/fso6.pdf (geraadpleegd op 17 januari 2001 ).

126 S. de Snith, R. Brazier, a.w., p. 296 met verschillende voorbeelden. Zie ook het Second Report from the Select Committee on Procedure warin het systeem is gedvalueerd: HC 19 (1989-90) en First Report from the Liaison Committee d.d. 3 maart 2000 (noot 123).

127 Furst Report from the Select Committee on Liaison d.d. 13 maart 1997, www. publications.parliament. /cmselectemlaisn/323i/lc0104.htm (geraadpleegd op 6 december 2000), maar vooral ook First Report from the Liaison Committee, Shifting the Balance: Select Committees and the Executive d.d. 3 naart 2000, a.w. net de reactie van de regering $(\mathrm{Cm} 4737)$ en een nieuw rapport van de Liaison Committee: Second Report from the Select Committee on Liaison, Independence or control? d.d. 25 juli 2000, ook te radplegen via www publications. parliament.. 00/cmselect/ cmliaisn/748/74803 htm (geraadpleegd op 20 december 2000 ).

128 Dit hangt mogeljk samen net het feit dat - zoals de Liaison Committee vorig jaar signaleerde - de politieke carriere wan de MP's wellicht meer gedicnd wordt door partijwerkzamheden an activiteiten "on the floor of the House" dan door het werken bimnen Select Committees. Zie First Report, a.w., p. 2.

129 Parliamentary Discussion Pursuant to Liaison Committee Report, Official Repont, 13 juli 2000 , Column $1085 \mathrm{e}$. Ook te radplegen via www publications." parliament ul/polcru99900/cmhansnd/cm000713/debtext/00713.12.htm 
argumentatie angstwhlig vermeed. Ei bligt wit dat als het erop aankont de Brise regering in de House of Commons heer en meester is.

Wat zouden deze ervaringen kumen betekenen voor de Nederlandse situatie? Wat nitet wil bepleiten is dat in Nederland het stelsel van Select Committees zonder meer word overgenomen. Een belangrijk versehil tussen beide landen bestaat reeds hieruil dat in de House of Commons veal meer 'backbenchers' zijn die het werk van dergelike commissies voor hun rekening kunnen nemen dan in de Nederlandse Tweede Kamer. Wel laat de Engelse ervaring zien dat cen parlement - ondanks dat het afhankelijk is van de regering - zichzelf zodanig kan hervomen dat zij har taken beter gaat uitoefenen. Bovendien wordt er door aangetoond dat een goede organisatie van commissiewerk zaamheden meer structuur en continutieit kan brengen in de parlementaire controle.

Aan dat laatste is ook in Nederland duidelijk behoefte. IK maak daarover wae korte opmerkingen. In de eerste plaats zou in de Tweede Kamer min of meer naar het Engelse vootbeeld een commissie kunnen worden ingesteld die zich in algemene zin verantwoordelik voelt voor het controlebeleid van de Tweede Kamer. Van Schagen heft reeds een vergelijkbaar voorstel gedaan in zijn Utrechtse dissertatie in $1994^{130}$ Een dergelijke commissie zou een belangrijke taak kunnen krijgen bij het selecteren van de beileidsthema's waar - mede gelet op de in het regeerakkoord gestelde prioriteiten - de Kamer zich gedurende een bepaalde periode op gaat richten. Bij de controle op de geselecteerde teremen zijn vervolgens allerlei modaliteiten denkbaar. ${ }^{131}$ In veel situaties kan wellicht worden volstaan net controle via de bestaande kanalen, zoals bijvoorbeeld via de procedure Controle Grote Projecten. Daarnast is het echter gewenst dat de Kamer meer dan nu het geval is onderzoek uitbesteedt aan exteme deskundigen of zelf onderzoek vernicht. Dit laatste kan geschieden door de vaste Kamercommissies of subcommissies daaruit en zou doorgaans veel minder grootsclalig moeten zijn dan de parlementaire enquêtes en onderzoeken die tot dusverre hebben plaatsgevonden. Het effect kan zijn dat Kamercommissies door zelf bronnen te radplegen, deskundigen te thoren en vervolgens over hun bevindingen te rapporteren, niet alleen meer voorspebaarheid en continuite it in hun controlewerk inbouwen, maar ook de inhoudelijke kwaliteit wan de controle op exn hoger niveau brengen. Uiteraard zal deze verandering in werkwijze de nodige investeringen vergen; niet in de laatste plaats zal een zekere uitbreiding van de staf noodzakelijk zijn.

Een tweede opmerking betreft het instrumentarium. Op dit moment heef de Kamer en beperkt antal controlebevoegdheden varierend van licht (het vragenrecht) tot zeer zwaai (de enquête). Wat opvalt is dat volwaardige tussenvormen ontbreken. Minder zware onderzoeken dan de politiek zwaar beladen enquêtes

130 J.A. van Schagen, a.w., p. 298. Zie ook G.H. Hagelstein, a.w, p. 397 e.v.

131 Binnen de Tweede Kamer bestat over de te volgen koers ernstige verdeeldheid. Zie NRC Handelsblad 17 januar 2001. Zie over voorgenomen veranderingen de toesprak van Kamervoorzitter van Nieuwenhoven ter gelegenheid van de presentatie van het boek 'Politieke veranderingen in Nederland, 1971-1998', Den Haag 23 juni 2000, alsmede har nieuwjarstoespraak d.d. 16 januari 2001, te vinden onder Wwa parlement al/odk/pbe/does/pbe2.hm (geraadpleegd op 23 januari 2001). 
komen in de praktijk wel woor, maar geschieden niet volgens een vast en geregeld stramien. Dit leidt tot onzekerheid en soms ook wel tot verschill van opvatting tussen Kamer en ministers en binnen de Kamer zelf over de werkwijze die moet worden gevolgd. Denkbaar is dat op dit punt - net zoals dit is geschied bij de Britse Select Conmittees - procedures worden ontwilkkeld die het gemakkelijker maken om dergelijke instrumenten op een effectieve en zorgvuldige manier in te zetten. Dit zou ook kunnen bevorderen dat ministers en ambtenaren tegenover de Kamer een minder verkrampte houding aannemen.

\section{De afrekencultuur}

Dit brengt mij op het tweede probleem in de huidige werkwijze van de Kamer: de afrekencultuur. $\mathrm{k}$ zei het al eerder: als er binnen de overheidsorganisatie of daarbuiten dingen zijn misgelopen bestaat er een sterke neiging om met de wetenschap van nu vast te stellen wie de fout heeft begaan en welke gevolgen dat voor betrokkene zou moeten hebben. Deze houding lijkt ook steeds dominanter te worden in de controle door de Tweede Kamer. Op het eerste gezicht staat de staatsrechtbeoefenaar hier met lege handen. De binnen het parlement heersende cultuur is vooral een politieke, geen staatsrechtelijke kwestie. Bij nadere beschouwing ligt dit ingewikkelder. Een belangrijke overweging daarbij is dat de afrekencultuur een negatieve invloed heeft op het functioneren van de ministeriële verantwoordelijkheid.

Naar algemeen wordt aangenomen moet in ons huidige staatsrecht een onderscheid worden gemaakt tussen de mimisteriëte verantwoordelijkheid en de toepassing van de vertrouwensregel. Deze onderscheiding is ook voor ons onderwerp van belang. De vraag of een minister uitleg behoort te geven over departementaal handelen dient te worden onderscheiden van de vraag of vanwege ambtelijk falen het vertrouwen in de desbetreffende minister moet worden opgezegd. In confesso is inmiddels dat het bij de eerste vraag er niet toe doet of de minister persoonlijk een verwijt treft. Bij beantwoording van de tweede vraag wordt het meewegen van die omstandigheid daarentegen niet uitgesloten. ${ }^{132}$ De achterliggende gedachte is dat de beoordeling van een bewindspersoon - anders dan de omvang van de ministeriële verantwoordelijkheid - een politieke kwestic is waar allerlei factoren een rol kunnen spelen.

In het Verenigd Koninkrijk speelt dit onderscheid in de zojuist bedoelde zin nauwelijks een rol. De vraag onder welke omstandigheden een minister behoort af te treden wordt in de handboeken veelal behandeld in het kader van de doctrine van de ministeriele verantwoordelijkheid. ${ }^{133} \mathrm{lk}$ heb eerder uiteengezet dat

132 P.P.T. Bovend'Eert, H.R.B.M. Kummeling, Vary Raalte's Het Nederlandse parlement, Deverter 2000, p. 221.

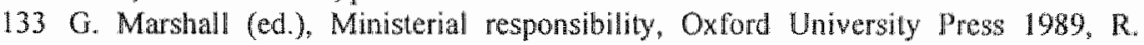
Brazier, Ministers of the Crown, Oxford 1997, p. 262 e. $v_{\text {, S. }}$. de Smith, R. Brazier, Constitutional and administrative law, Penguin books 1998, p. 190 e.v. IK laat hier de bijzondere positie van de Prime Minister in het Verenigd Koninkrijk buiten beschouwing. 
het naar heersende opvatting in het Verenigd Koninkrijk verschil maakt of ambtelijk falen veroorzaakt is door cen slechte organisatie of gebrekkig toezicht, dan wel door een individuele ambtenaar die buiten de minister on uit de pas loopt. In het eerste geval wordt de minister geacht de schuld volledig op zich te nemen en desnoods terug te treden, in het tweede geval ligt dit aanmerkelijk genuanceerder. De ministeriêle verantwoordelijkheid en de sanctionering daarvan lopen hier door elkaar heen. Het laat tevens zien dat de vooral in Nederland bekende Carrington-doctrine in het Britse staatsrecht niet bestaat of daarin althans niet hecht verankerd is. Sinds de Tweede Wereldoorlog ${ }^{1.34}$ zijn in het Verenigd Koninkrijk vele ministers afgetreden, maar slechts in een enkel geval was de aanleiding gelegen in ambtelijke tekortkomingen. En zelfs in die spaarzame gevallen - Sir Thomas Dugdale in de befaamde Crichel Down Case in 1954, ${ }^{135}$ Lord Carrington in de Falkland-crisis in $1982^{136}$ en Brittan in de eerder besproken Westland-affaire ${ }^{137}$ - bleek de zaak achteraf gezien genuanceerder. Er was meestal reden on aan te nemen dat de desbetreffende minister wel degelijk ook een persoonlijk verwijt kon worden gemaakt.

Uit de Engelse ervaring blijkt eens te meer dat het bij ons bestaandle onderscheid tussen ministeriele verantwoordelijkheid en vertrouwensregel niet alle problemen oplost. Met het oog op de toepassing van het verwijtbaarheidscriterium geeft het alleen een schijnduidelijkheid. Beide leerstukken zijn in hun praktische toepassing nauw met elkaar verweven. Het meewegen van de verwijtbaarheid bij de beoordeling van het functioneren van een minister, leidt tot een ongewenste reflexwerking bij het afleggen van ministerielle verantwoording. Het leidt ertoe dat de Tweede Kamer zich concentreert op de vraag aan wie een bepaalde fout te wijten is en of de minister daarbij persoonlijke betrokkenheid beeft gehad. Daardoor wordt een minister in de verleiding gebracht om de schuld af te schuiven op zijn ambtenaren; hij maakt dan meer kans om in de Kamer "goed weg te komen". ${ }^{138}$ Op deze wijze sluipt de verwijtbaarheid als relevante factor bij de ministeriële verantwoordelijkheid - hoewel volgens de doctrine niet relevant - langs een achterdeur weer binnen.

Zuiver geredeneerd zou dit tot de conclusie moeten leiden dat ook bij de toepassing van de vertrouwensregel het verwijtbaarheidscriterium geen rol van betekenis mag spelen. ${ }^{139}$ Indien in een concreet geval blijkt dat de overheid niet goed

134 Ook uil de geschiedenis wan woor de Tweede Wereldoorlog kan een dergelijke doctrine niet worden afgeleid. Zie S.E. Finer, The individual responsibility of ministers, Public Administration 34 (1956), p. 377 e.v., ook gepubliceerd in G. Marshall (ed.), a.w. p. $115 \mathrm{e.v}$.

$135 \mathrm{G}$. Marshall, Individual responsibility: sone post-war examples, in: $\mathrm{G}$. Marshall (co.), a.w. p. 130, R. Brazier, a.w., p. 275.

136 I. de Ridder, Verzelfstandiging en het primat van de politiek, Beleid \& Maatschappij 1998, p. 128. Zie ook I. Loveland, a.w., p. 268.

137 G. Marshill, a.w., p. 133.

138 M. Schiltema, a.w., p. 1863.

$139 \mathrm{Vgl}$. H.G. Warmelink, Ministerigle verantwoordelijkheid voor ambtelijk handelen, in: D.J. Elzinga, (red.), Ministeris/e verantwoordelijkheid in Nederland, Zwolle 1994, p. 103 e.v., m. p. 109 
heef gefunctioneerd dient het bij de beoordeling van de verantwoordelijke minister te gaan om de ernst van de fouten die onder zijn verantwoordelijkheid zijn gemaakt en het vertrouwen dat de Kamer in dat licht bezien nog heeft dat de zittende minister in de toekomst kan bijiven functioneren. Daarbij moet niet worden uitgesloten dat een minister vanwege ambtelijk fallen moet heengaan, ook al heeft hij aan dat falen in persoonlijke zin part noch deel. Het ontslag kan in die situatie primair fungeren - zoals Donner het in zijn befaamd geworden bijdrage heeft uitgedrukt - als 'zweepslag voor de betrokken ambtelijke dienst'. ${ }^{140}$ De vertrekkende minister maakt dan ruim baan voor zijn opvolger om orde op zaken te stellen. Dat in die situatie falende ambtenaren vrijuit zouden gatan zoals soms wel is gesuggereerd ${ }^{141}$ - berust op een ernstig misverstand.

Het bovenstaande mag niet worden opgevat als een pleidooi voor veelvuldig 'koppen rollen'. Indien een ramp, een schandaal of een andere vorm van tegenspoed al het gevolg is van een tekortschietende overheid - hetgeen soms te gemakkelijk wordt aangenomen ${ }^{142}$ - zou de aandacht in de eerste plaats moeten uitgaan naar de vraag hoe ministers, ambtenaren en ook Kamerleden zelf het in de toekomst beter kunnen doen. In bijzondere situaties zullen personele consequenties echter onvermijdelijk zijn.

Er kan mij worden tegengeworpen dat de benadering die ik voorsta niet erg realistisch is. Cynici zouden kunnen opmerken dat het in de politiek nu eenmaal vaak gaat om de vraag bij wie de zwarte piet kan worden neergelegd. Daar wil ik tegenover stellen dat deze werkwijze het aanzien van de politiek geen goed doet. Ministers komen wel vaak onder politieke druk te staan, maar treden zelden of nooit af. Dat komt omdat het heengaan van een minister in de beeldvorming al snel gezien wordt als een bewijs dat de betrokkene persoonlijk niet goed functioneerde. ${ }^{143}$ Een bewindspersoon zal geneigd zijn dit tegen elke prijs te willen voorkomen. Hierdoor blijven politiek verantwoordelijke ministers te gemakkelijk zitten - ook in de uitzonderlijke gevallen waarin terugtreden vanwege ernstig fallen van de overheidsorganisatie voor de hand zou hebben gelegen terwijl als de nood echt aan de man komt de gevolgen te gemakkelijk worden afgewenteld op individuele ambtenaren. Deze gang van zaken is schadelijk voor het functioneren van de ministeriële verantwoordelijkheid en woor ons parlementair stelsel als geheel.

140 A. M. Donner, a.w. p. 367. Zie ook J.Th.l. van den Berg, Ministeriele verantwoordelijkheid: 'De zweepslag voor de ambtelijke diensu', Socialisme en democratic 1989 , p. 124.

141 H. wan Maarseveen, Reidans der niet-werantwoordelijken, NHB 1987, p. 1516.

142 M. Kranenburg, Alle rampen de wereld uit, NRC Handelsblad 19 januari 2001.

143 Zie ook Steekhoudend ministerschap, a w w. p. 15 warin onder meer on deze reden gepleit wordt voor terughoudende toepassing van het verwijtbaarheidscriterium bij toepassing van de vertrouwensregel. 


\section{Afronding}

IK vat her geheel samen met een enikele conclusie.

Mign vertrekpunt was de veranderde positie van de ambtenaar. De zwoeger in het vooronder van weleer bestaat niet meer. Hij is uit het vooronder omhooggekomen en staat nu wak in het volle licht van de schijnwerpers. Deze ontwikkeling heef mede tot gevolg gehad dat de ministeriele verantwoordelijkheid voor het functioneren van de ambtelijke dienst de laatste jaren voortdurend onder druk staat. In de discussie daarover wordt vaak gepleit voor het terugdringen van deze verantwoordelijkteid. Naar mijn mening biedt dit geen oplossing. Het is ook riskant. In feite betekent het dat we ons parlementair stelsel afbreken zonder dat ons een helder alternatief voor ogen staat.

Zolang we vasthouden aan ons parlementaire stelsel, moeten we onze energie vooral steken in verbetering van het functioneren daarvan. De ministerièle verantwoordelijkheid is daarvoor geen belemmering. Zij moet niet worden gehanteerd als een strak keurslijf, maar als een algemeen organisatieprincipe waarbinnen ruimte is voor verandering. Ambtenaren moeten in die structuur kunnen beschikken ower ruime bewegingswrijheid, mits de vertrouwensrelatie met de minister centraal blijft staan. Dat besef blijkt niet altijd in voldoende mate aanwezig. Zowel ambtenaren als ministers dienen meer te investeren in het onderlinge vertrowwen dan nu het geval is. $1 \mathrm{k}$ heb in deze rede geprobeerd daartoe enkele concrete oplossingsrichtingen an te geven, waarbij ik inspiratie heb geput wit het Britse staatsrecht.

Echte resultaten zijm echter alleen te boeken als ook de Tweede Kamer zijn werkwijze aanpast. Dit aspect blijft vaak onderbelicht. De eenzijdige fixatie op de ministeriele verantwoordelijkheid die de discussie over het functioneren van het openbaar bestuur lijkt te beheersen, moet plaatsmaken voor een evenwichtiger benadering warin ook de rol van ons parlement serieuze aandacht krijgt. De Kamer moet zijn controlerende taak gestructureerder en minder persoonsgericht uitoefenen.

\section{Minheer de rector magrificus, dames en heren,}

Aan het eind wan mijn rede gekomen stel ik het op prijs het College van Bestuur en al degenen die arn mijn benoeming aan deze universiteit hebben bijgedragen, to danken voor bet in mij gestelde vertouwen.

\section{Dames en heren studemen,}

Het studentenleven ziet er tegenwoordig anders uit dan door Klikspaan werd beschreven. Studeren is een niet geringe opgave; in korte tijd moet $u$ een intensief programma afwerken, terwijl er daamaast nog zoveel andere dingen zijin die uw aandacht vragen. Bij het laatste kan ik u moeilijk helpen, bij het eerste wel. U zult in uw studie veel zelf moeten doen, maar ik zal mij inspannen u darbij $z 0$ goed mogelijk bij te staan. 
Leden van de redactie wan het NJCM-Bulletin

In mijn periode als actief lid van het Nederlandse Juristencomite voor de Mensenrechten heeft mijn belangstelling voor het vakgebied vaste vorm gekregen. Het is voor mij een groot genoegen om vele jaren later met bevriende collega's die ik meestal in die tijd heb leren kennen, deell uit te maken van de redactie van dit eerbiedwaardige vaktijdschrift. Wellicht heeft mijn rede bij jullie de gedachte doen postvatten dat ik in mijn wetenschappelijke werk de grondrechten vaarwel zal zeggen. Het tegendeel is echter het geval. De grondrechten blijven naast het 'gewone' staatsrecht voor mij een belangrijk aandachtsgebied.

\section{Leden van de vakgroep staats- en bestuursrecht van de Universiteit Unecht}

Ik denk nog wel eens terug aan die mooie jaren dat ik in jullie midden mocht vertoeven. Mijn wetenschappelijke vorming heeft in belangrijke mate in die periode plaatsgehad. We waren een hechte groep waarin goed presteren gepaard ging met een uitstekend werkklimaat. Het doet mij dan ook veel plezier velen van jullie opnieuw te ontmoeten, onder meer in het kader van onze samenwerking in de onderzoekschool lus Commune. Ik ben ervan overtuigd dat wij deze samenwerking de komende jaren verder kunnen uitbouwen.

\section{Waarde Burkens, beste Marten}

In de Utrechtse vakgroep nam jij wel een zeer bijzondere plaats in. Een staatsrechtbeoefenaar kan zich geen betere leermeester wensen. Met je scherpe wetenschappelijke inzichten, je stimulerend vermogen en je grote integriteit ben je tot op de dag van vandaag voor mij een lichtend voorbeeld.

\section{Oud-collega's van de directie wetgeving van het ministerie van Justitie}

De titel en de inhoud van deze rede zijn mede door jullie geînspireerd Want gezwoegd hebben we daar in die grote flat aan de haven. De kennis en ervaring die ik bij jullie heb opgedaan zijn voor mij zowel in zakelijk als in persoonlijk opzicht van onschatbare waarde geweest. Anders dan de krantenberichten wellicht soms deden vermoeden, werden de werkverhoudingen altijd gekenmerkt door collegialiteit en soms door onderlinge vriendschap. I $k$ hoop en verwacht met velen van jullie ook vanuit het verre Maastricht het contact te kunnen blijven onderhouden.

\section{Leden van de faculteit der rechtsgeleerdheid}

Mij is onlangs de opmerking ten deel gevallen dat ik snel in de faculteit ben ingeburgerd. Dat is vooral te danken aan de gastvrijheid waarmee ik door jullie ben ontvangen. We vormen een faculteit waar de lijnen kort en de contacten informeel zijn. Dat zijn goede randvoorwaarden om de komende jaren gezamenlijk het onderwijs en onderzoek op een kwalitatief hoog peil te houden. Ik zal mijn best doen om daaraan mijn steentje bij te dragen.

\section{Leden van de capaciteirsgroep publiekrecht}

Bij jullie heb ik mij vanaf het begin volledig thuisgevoeld. Ik heb mogen kennismaken met een enthousiaste, hardwerkende en kwalitatief veelbelovende groep mensen met een grote onderlinge saamhorigheid. Dat schept vertrouwen voor de toekomst. Ik verheug mij erop om samen met jullie de komende jaren het staats- 
en bestuursrechtelijke onderwijs en onderzoek aan onze faculteit te verzorgen en waar nodig verder uit the bouwen. Daarvoor zijn in het bijzonder ook de leden van ons secretariaat onmisbaar. Nettie Litjens en Bregtje Schwenke hebben onder meer tijdens de voorbereiding van deze rede veel werk voor mij verricht, waarvoor ik hen hartelijk dank. In dat verband dank ik ook mijn student-assistente Nynke Schroder die mij ten behoeve van deze rede heeft voorzien wan belangrijk materiaal.

\section{Waarde Stroink en Heringa. Beste Frits en Aalt Willem}

Het is voor mij een groot voorrecht om met jullie als naaste collega's te mogen samenwerken. Onze verhouding is er een wan hartelijkheid en loyaliteit. Voor de wijze waarop jullie mij in de eerste periode hebben ondersteund en wegwijs gemaakt aan deze faculteit en soms ook daarbuiten, heb ik veel waardering. Indien ik spreek over wegwijs maken noem ik ook de derde collega in de capaciteitsgroep: Ad Geers. Beste Ad, van je wijsheid en humor heb ik veel profijt en plezier. Daarnaast heb je er in belangrijke mate toe bijgedragen dat ik vanuit de cullinaire woestenij in de Randstad geruisloos in het Bourgondische deel van Nederland ben neergestreken.

\section{Lieve Janet, Dorine en Michelle}

Het is overdreven om te stellen dat we een rustig jaar achter de rug hebben. Vooraf heb ik mij wel afgevraagd wat ik jullie met ons vertrek uit Leiden zou aandoen. Als ik echter zie waar we nu staan, dan geloof ik dat we erin geslaagd zijn om - mede dankzij hulp van familie, vrienden en collega's - in korte tijd een eigen plaats in deze prachtige stad te verwerven. Wat mijn werk betreft zijn er andere verworvenheden; ik beschik nu over een gepast kostuum waardoor ik mij eindelijk kan meten met de kleurrijke prinsessenjurken die jullie thuis bijna dagelijks uit onze verkleedkist tevoorschijn toveren.

Vanzelfsprekend gaan mijn gedachten op deze dag uit naar mijn vader, Jef Verhey: zoon van deze stad. Hoewel hij nog geweten heeft dat wij naar Maastricht zouden komen, heeft het niet meer zo mogen zijn dat hij hier vandaag bij ons is. Het is voor mij een grote eer om in zijn stad en aan de universiteit aan de ontwikkeling waarvan hij heeft bijgedragen, het ambt van hoogleraar te mogen aanvaarden. Aan hem draag ik deze rede op.

Ten slotte dank ik allen voor uw komst.

Ik heb gezegd. 